Portland State University

PDXScholar

5-8-1992

\title{
Corporatism in American Foreign Policy Toward Germany Between the Wars, 1921-1936
}

William R. Martin

Portland State University

Follow this and additional works at: https://pdxscholar.library.pdx.edu/open_access_etds

Part of the History Commons, and the International Relations Commons Let us know how access to this document benefits you.

\section{Recommended Citation}

Martin, William R., "Corporatism in American Foreign Policy Toward Germany Between the Wars, 1921-1936" (1992). Dissertations and Theses. Paper 4380.

https://doi.org/10.15760/etd.6264

This Thesis is brought to you for free and open access. It has been accepted for inclusion in Dissertations and Theses by an authorized administrator of PDXScholar. Please contact us if we can make this document more accessible: pdxscholar@pdx.edu. 
AN ABSTRACT OF THE THESIS OF William R. Martin for the Master of Arts in History presented May 8, 1992.

Title: Corporatism in American Foreign Policy Toward Germany Between the Wars, 1921-1936.

APPROVED BY THE MEMBERS OF THE THESIS COMMITTEE:
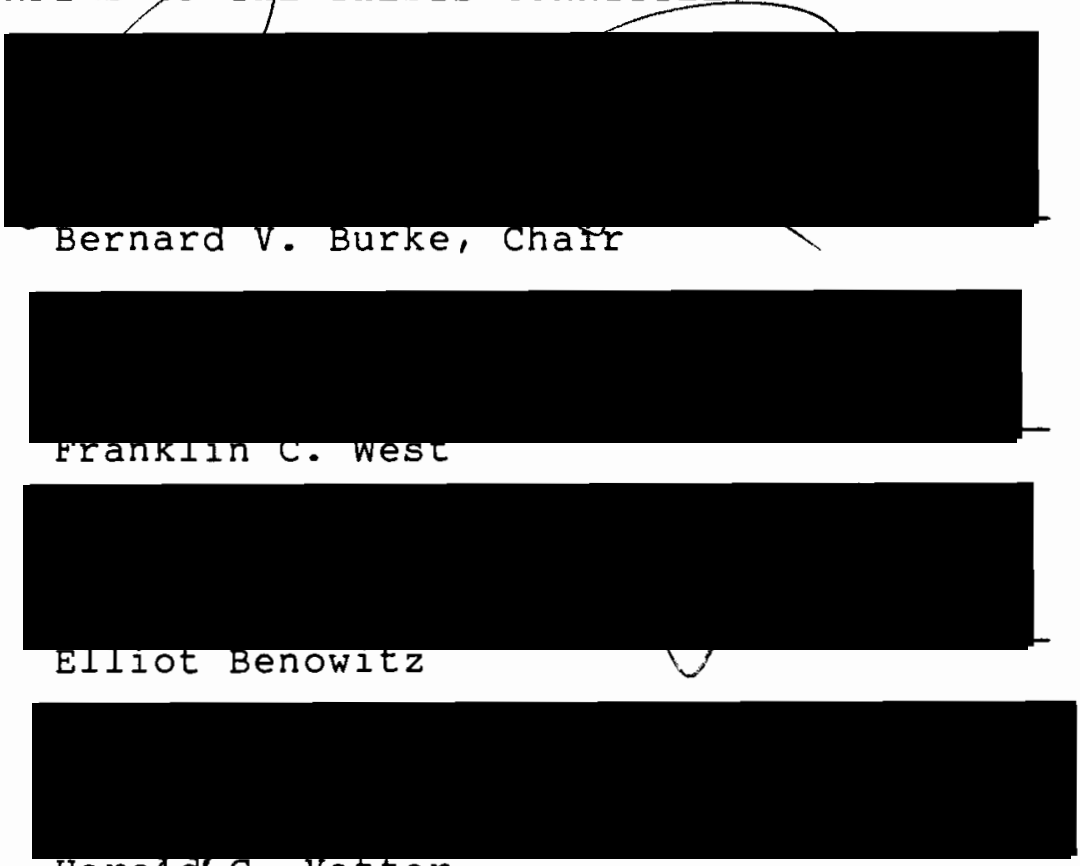

Harod'G. vatter

This thesis is an investigation of how United states foreign policy was made in the context of German-American relations in the period between the two world wars. The problem under investigation is whether the United states was using a corporatist approach in dealing with the problems of Germany and ultimately Europe and whether the corporatist model is a good one for analyzing foreign policy 
development during this period. Corporatism, as it is used in this thesis, is defined as an organizational form which recognizes privately organized functional groups outside the United states government, which collaborate with the government to share power and make policy. In the case of foreign policy, the focus of this investigation is on the role played by autonomous financial experts, especially from the banking community.

The data used in making this investigation comes from secondary sources, both books and articles, and primary sources. The books are works written by historians which cover both the entire period, specific crisis points in the period, and biographies of the main people involved, usually focusing on their foreign policies. A number of articles are also cited and these deal both with specific problems of the period and also with questions of historiography, especially corporatist historiography. In addition, primary sources make up a significant amount of the data. These include both memoirs of the key individuals involved in foreign policy and also documents on foreign policy of both the United States and Germany, the latter consisting primarily of correspondence between the chief government officials involved in foreign policy. The university library is certainly adequate for an investigation of this type, though naturally a certain amount of the primary documentation for such a project can 
not be found in one library as it is stored in archives in in other parts of both the United states and Germany. The results of this investigation can be summarized as follows: the corporatist approach was used and the model is valid for examining diplomacy in the 1920's, but fails to explain what happened in the 1930's. The methods involved in formulating policy to deal with Germany and Europe changed significantly from the Republican administrations of the 1920's to the administration of Franklin D. Roosevelt. The change actually began partially under President Hoover, one of the original "associationalists", associationalism being another word used by historians to describe corporatism. It is thus concluded that the corporatist model serves some periods better than others and is therefore not the ideal vehicle for the examination of foreign policy making over longer periods of time. 
CORPORATISM IN AMERICAN FOREIGN POLICY TOWARD GERMANY BETWEEN THE WARS, 1921-1936

by

WILLIAM R. MARTIN

A thesis submitted in partial fulfillment of the requirements for the degree of

\author{
MASTER OF ARTS \\ in \\ HISTORY
}

Portland State University

1992 
TO THE OFFICE OF GRADUATE STUDIES:

The members of the committee approve the thesis of William R. Martin presented May, 8, 1992.
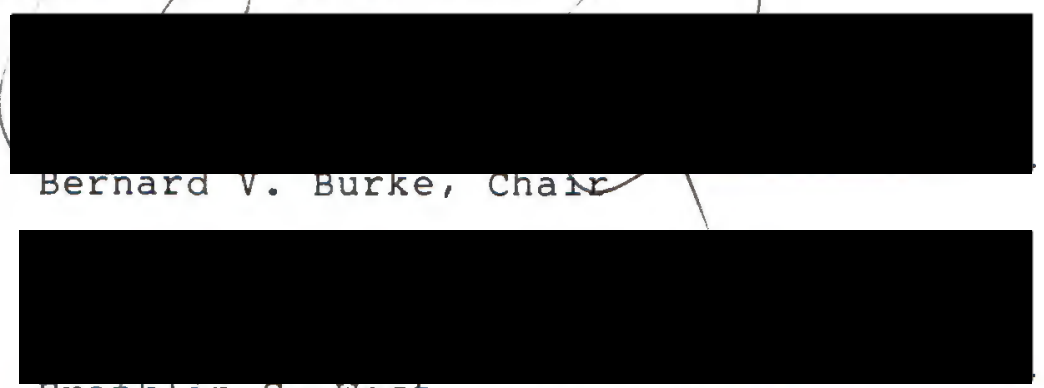

Franking c. west
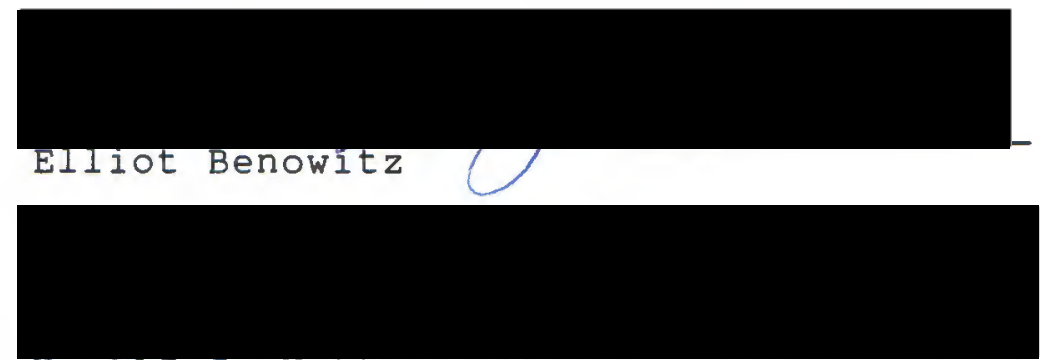

Hagold G. Vatter

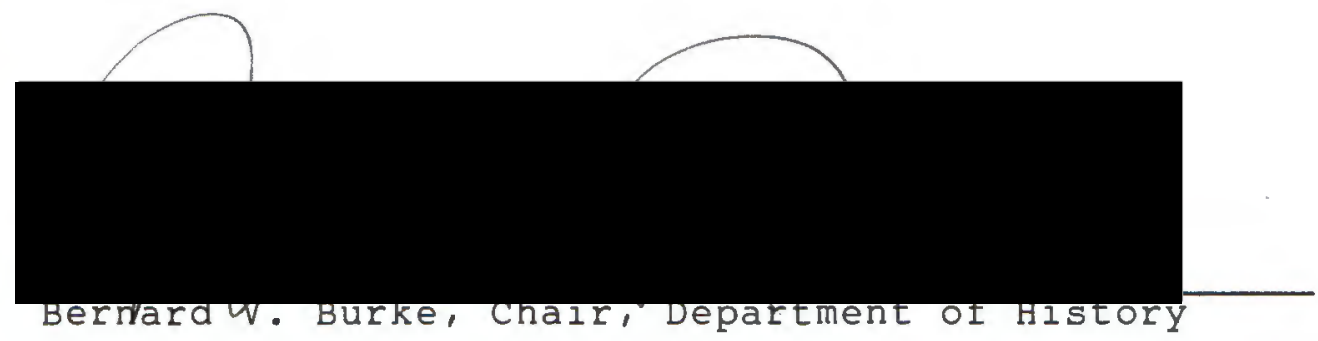

C. William Savery, Interim vige provost for Graduate studies and Research 
TABLE OF CONTENTS

CHAPTER

PAGE

I INTRODUCTION . . . . . . . . . . . . . . . . 1

Endnotes for Chapter I. . . . . . . . . 8

II CORPORATIST BEGINNINGS . . . . . . . . . . . . . 9

Endnotes for Chapter II...... . . . 30

II THE DAWES PLAN AND APOLITICAL DIPLOMACY . . . 33

Endnotes for Chapter III. . . . . . . . . 45

IV THE LOAN POLICY: COORDINATION GONE AWRY . . 47

Endnotes for Chapter IV. . . . . . . . . 66

V CORPORATISM UNDER STRESS: THE HOOVER YEARS. . 68

Endnotes for Chapter V . . . . . . . . . 84

VI ROOSEVELT AND THE END OF CORPORATISM IN

FOREIGN POLICY . . . . . . . . . . . . . . 87

Endnotes for Chapter VI. . . . . . . . 105

VII UNCERTAINTY OF POLICY APPROACH IN THE

MID-1930's . . . . . . . . . . . . . 107

Endnotes for Chapter VII . . . . . . . . 129

VIII CONCLUSION . . . . . . . . . . . . . . . . 133

REFERENCES . . . . . . . . . . . . . . . . . . . 136 
CHAPTER I

\section{INTRODUCTION}

The purpose of this thesis is to examine the effect of corporatism on the relations between the United States and Germany in the 1920's and 1930's. I believe the corporatist model is a good one for examining the relations in the $1920^{\prime}$ s but is found wanting in explaining German-American dealings in the 1930's, especially from 1933 on when both Adolf Hitler and Franklin D. Roosevelt had assumed power. The corporatist historians that have been writing over the past two decades seem to skip over this period as though it was an aberration and pick up corporatist development in the post-World war II period. But this is not helpful in examining how relations were carried out if the corporatist model is indeed useful for explaining diplomatic history in any given period as the proponents would have it.

Traditionally, diplomatic historians have interpreted the history of American foreign policy through dichotomies, or competing opposites. These have usually included isolationism versus internationalism, idealism versus realism, imperialism versus anti-imperialism, and revolutionary versus reactionary paradigms. The corporatist revisionism seeks a unifying synthesis to explain the conduct of foreign policy rather than 
relying on these dichotomies. The old dichotomies still have some worth however, and I believe the balance between rule by elite versus rule by democratic forces is a useful one to examine in the context of foreign policy in the $1920^{\prime} \mathrm{s}$ and 1930's.

American diplomatic history began after world war 1 with the nationalist perspective of Samuel Flagg Bemis and Dexter Perkins. This approach emphasized the emergence of the United States as a world power and described traditional European style balance of power, bilateral diplomacy. The progressive, or revisionist historians, led by Charles Beard, focused more on the intellectual foundations and conflict-induced change which guided American foreign policy. This led to the critical realist historiography of the 1950's and 1960's, exemplified by those like George Kennan, who concerned themselves with elites creating policy to pursue nationalist aims. They emphasized geopolitics and were critical of the influence of domestic pressures. The revisionists of the 1960's and 1970's, such as william Appleman Williams, focused more on idealism and the wayward capitalism that led to such ill-founded ventures as the vietnam war. This economic causation approach was modified by postrevisionists, such as John Lewis Gaddis, who tended toward seeing policy as a reaction to the threat of soviet expansion, rather than a result of U.S. expansionist desires. ${ }^{1}$ 
Thomas G. Paterson maintains that diplomatic historians concentrate on four basic levels: international, regional, national, and individual. ${ }^{2}$ Corporatist historians take all of these levels into consideration in their attempt to include both internal and external factors in policy making. The corporatist approach is most concerned with describing the organizational form of foreign policy formulation. Corporatist historians have described not only the components of the American system that have influenced foreign policy, but also, as with Charles Maier, the corporatist reorganization of Europe in the $1920 \mathrm{~s} .^{3}$

Corporatist historians, such as Michael J. Hogan and Maier, define corporatism as an organizational form between traditional laissez-faire capitalism and state control of enterprise and policy. It recognizes privately organized functional groups outside of the government, most commonly business, labor, and agriculture, which through coordinating mechanisms collaborate with the government to share power. In this way public policy results from semiautonomous agencies of nonpartisan experts. For the purpose of this analysis, business interests figure more heavily into the foreign policy equation than do agriculture or labor, thus they will play a more prominent role in this analysis. More roughly put, these sectors become bargaining units, along with the government, which acts also as a mediator, and a certain equilibrium is reached. This was certainly the case 
in Germany in the 1920's as described by Maier, though the equilibrium was certainly fragile. 4

critics of the corporatist model, such as Gaddis, believe that it serves certain periods very well, such as the 1920's, when there was broad agreement towards foreign policy, but not for other periods, such as the 1930's, which lacked consensus.5 He goes on to criticize corporatism for ignoring differences within the functional groups, such as the division between the international finance sector of business and those middle to small sized concerns that that were more interested in the domestic market. Gaddis also maintained that corporatist theory ignores how the geopolitical situation effects U.S. policy (for example, the increasing militancy of Nazi Germany), it downplays ideals (such as President Wilson's post-war internationalist cooperation), and that it ignores the roles of individuals (except for Herbert Hoover). ${ }^{5}$ proponents of corporatism, such as Hogan, refute these criticisms with examples such as the attention leading bankers received; the divisiveness of the 1920's; that the emphasis is not on consensus but on power formation, and that geopolitical considerations were the key to post-World War II internationalism, as well as the Republican vision of American prosperity and world stability in the 1920's.

Corporatist historians are concerned with organizational developments in the twentieth century. ${ }^{6}$ 
Capitalism in the late nineteenth century was dominated by individuals, or the captains of industry, in the United states. What economic historians call the organizational revolution began around the turn of the century and was characterized by the rise of the corporation as the primary form of big business management. The leading politicians of the time, led by Progressives like President Theodore Roosevelt, did not fight this development, but saw it as necessary to counter the cartels which had developed in Europe. Roosevelt wanted these corporations to work in concert with the government and accept some restraint in the interests of the American people. The government would act as a mediator between corporate concerns and other groups, such as labor. If this was the genesis of the corporatist idea, the actual practice of it occured during World War I, with the introduction of the war Industries Boards, which established the pattern of business-government collaboration meant to ensure the most efficient production and use of resources for the prosecution of the war.

Michael J. Hogan emphasizes the need for diplomatic historians to develop a framework that deals with both the domestic and international forces that shape policy. ${ }^{7}$ As a leading proponent of corporatist theory, he believes it is an adequate model because it describes the organization of decision making. It deals with functional elites in the leading organized groups (like business, labor and 
agriculture) and how they inter-act with government. The role of traditional governing classes is de-emphasized. The dynamics of the business-government collaboration form the basis for foreign policy analysis in this model. Hogan speaks of a New Deal coalition that "elaborated the corporative design envisioned by Republican leaders a decade earlier". 8 But the New Deal focus was on domestic policy. In the 1920's, Republicans collaborated with industry and finance to push traditional open Door policies and dollar diplomacy. Government would join, in an associational relationship, with nonpartisan "expert" commissions to scientifically solve problems of war debts and tariffs and find the key to economic and thus political stability. Hogan goes on to state that good corporatist historians show how the system was flawed and led in part to the economic collapse of the 1930's as well as showing that party politics, congressional pressures, and public opinion all played a significant role. ${ }^{9}$

Melvyn P. Leffler says that the contrasting themes of political isolationism and economic expansionism are useful frameworks for investigating American foreign policy between the wars. They just don't go far enough toward a complete synthesis. 10 He doesn't believe that American policy makers were naive in failing to make political commitments or ignoring the political realities, nor does he believe that the United States was setting up an international economic 
system that would ensure its predominance. He feels the answer is somewhere in between, that the United states wanted European stability not only for its own sake but to further American self-interest as well. The problem, as he outlines it, was how to achieve this while maintaining domestic priorities and staying out of European conflicts that were not vital to American interests. ${ }^{l}$

The corporatist vision stems from the belief that there is a multiplicity of causes, both internal and external, and that there are many participating groups in the formation of international relations. Charles s. Maier reminds us that the political philosopher Thomas Hobbes pointed out in the seventeenth century that the international system is unique in that it has no sovereign and is not governed by a standardized system of laws. ${ }^{12}$ Instead it is a more haphazard system that develops according to international competition and takes into account political structures, cultural differences, and economic arrangements.

In this respect, economic considerations are extremely important to the study of German-American relations in the inter-war period. People in the business and financial worlds played leading roles in formulating policy, especially in the 1920's. The corporatist perspective incorporates these roles into a formal structure of decision making • 
ENDNOTES FOR CHAPTER I

1. Michael J. Hogan and Thomas Paterson (Eds.), "Introduction", Explaining the History of American Foreign Relations (New York, Cambridge University Press, 1991), p. 5 .

2. Thomas G. Paterson, "Defining and Doing: a Primer", Explaining the History of American Foreign Relations, p. 38 .

3. Charles S. Maier, Recasting Bourgeois Europe, (Princeton: Princeton University Press, 1974), general theme.

4. Ibid., general theme.

5. John Lewis Gaddis, "The Corporatist Synthesis: A Skeptical View", Diplomatic History, vol. 10, Fall 1986, p. 357 .

6. Corporatist historians generally include the following (among others): Michael J. Hogan, Charles $\mathrm{S}$. Maier, Thomas McCormick, Melvyn P. Leffler, Carl P. Parrini, Joan Hoff-Wilson, Frank Costigliola, and Ellis Hawley.

7. Michael J. Hogan, "Corporatism", Journal of American History, vol. 77, June 1990, p. $15 \overline{5}$.

8. Ibid, p. 155 .

9. Ibid, p. 157 .

10. Melvyn Leffler, "Political Isolationism, Economic Expansionism, or Diplomatic Realism: American Policy Toward Western Europe 1921-1933", Perspectives in American History, (New York, Cambridge: Cambridge University Press, 1984), p. 415 .

11. Ibid, p. 416 .

12. Charles S. Maier, "Marking Time: The Historiography of International Relations", in The Past Before Us, Contemporary Historical writing in the United States (Michael Kammen, ed., Ithaca, pcornell University Press, 1980), p. 386 . 


\section{CORPORATIST BEGINNINGS}

Corporatist historians maintain that the corporatist structure began taking shape with the Progressive Era, when government recognized the need to harness industrial growth and mediate among the main interest groups. On the international level, business feared destructive price competition and the hope was that government could contribute to stability.

Corporatism became institutionalized during World War I as War Industries Boards were set up to make the most efficient use of the nation's resources for war mobilization. These boards were composed of private civilian elites and executive branch appointees; a collaboration of business and government which determined price and production levels. ${ }^{l}$ These would serve as the model for corporatism and organized collaboration was the key. The degree of organization becomes critical for determining whether the corporatist model fits the 1930 's as well as it seemed to fit the 1920's.

Though the United States did not join the League of Nations after world War I, corporatist historians argue that the policy makers of the post-war period sought economic and 
financial structures that paralled the political cooperative structures of the League. ${ }^{2}$ some felt this development was anti-democratic because non-elected people were creating important policy that affected the nation. Ironically enough, as the elected representatives in the senate rejected an American participation in the League and the Versailles Treaty, they eliminated any American governmental presence on the committees that were set up to deal with the reparations problem. The result was that representation on these committees would end up consisting of prominent members of the financial world. This was a continuation of the war-time situation however. And as Beth Mckillen points out, many Americans were less than satisfied, especially those in the Labor movement, with this centralization of wartime economic power in executive appointees. $^{3}$ Dissatisfaction was felt by ethnic groups and middle-sized business, which complained of corporate domination of and profit from the boards. Mckillen believes this formed some of the opposition to the League and President wilson's view of a new internationalist order.

But despite opposition to this wilsonian view, American policy, through the action of private elites, reflected a desire for an international economic order. This calls into question whether the corporatist design was intentional and premeditated or merely arrived at by chance and circumstance. 
The Republicans who came into office in 1921 believed that economics would determine the level of peace and stability the world would experience. Growth and cooperation were essential in their eyes. Industrial and technological progress had made the world more economically interdependent. As Leffler points out, this was not necessarily an ideologically based notion, but one born of the realization that political and military balances and alliances had been inadequate to prevent world War I. ${ }^{4}$ Both prominent politicians, such as secretary of state Frank B. Kellogg and Senator William E. Borah, and prominent bankers and businessmen, like Owen D. Young, concurred in this belief that commercial and financial stability were the keys to peace and prosperity. ${ }^{5}$ They felt international problems could be solved scientifically through the use of "experts" and business methods which would take them out of the political realm. They would lead the way economically, maintaining the freedom to pursue their own national interests through the Open Door, which would in turn stimulate the world market and bring international economic stability. However, there were serious dangers in the failure to recognize the political ramifications of their economic policy, especially in Germany. Furthermore, the failure to publically admit and deal with the connection between allied war debts and German reparations payments, all the way through to and including Franklin D. Roosevelt, 
can also be seen as a critical misjudgement. The loan policy toward Germany, which offically began with the Dawes Plan in 1924, calls into serious question the degree to which government and the financial leaders closely coordinated their policy and actions, which reflects negatively on the corporatist vision.

This was clearly a transitional period for the United States. The 1920's was the last decade of laissez faire capitalism in the economic sphere and the long road from the nation's early fear of entangling alliances to interwar isolationism in the political sphere would soon come to a crashing halt as well. But coming out of World war I successfully and relatively unscathed, the United states emerged as the world economic superpower and had a moral egotism to match it. President Harding felt America was the greatest contributor to human welfare in history. He was followed by coolidge, who said "America first is not selfishness: it is the righteous demand of strength to serve." After this came President Hoover, who thought the American system was the promise of the human race. ${ }^{6}$ These attitudes and ideals combined with the fact that the U.S. emerged from the War as a creditor rather than a debtor nation. Republican policy would allow the private financial sector to pursue policies which amounted to foreign intervention while the public sector denied there were major political implications for this intervention, thereby 
maintaining the facade of isolationism and conforming to public and congressional sentiment.

If there was a failure to make connections between economic and political policies, there was also a failure to see certain economic connections that would have caused political conflict. If politicians were afraid to make the connection between allied war debts and reparations, bankers were equally cautious, if less naive, in prolonging this policy. The circular flow of money from American banks to Germany in the form of loans, went on to the former allies as hard currency reparations payments and then back to the United states as debt repayment. Both reparations and allied debt installments were scheduled to run into the $1980^{\prime} \mathrm{s}$. They barely lasted into the 1930's before payments were ended, first through a moratorium and then permanently by Hitler. But it was a political minefield to attempt cancelling debts. It was equally politically unpopular to bring down the tariff barriers, which would have been necessary to allow German exports into the United states to a degree to which they could realistically have contributed to Germany's hard currency reserve. If the Germans couldn't export to any significant degree they would be hard pressed to raise the hard currency needed for reparations transfers. The loan policy served as an escape hatch but would bring increasing pressure on the German government, both at the state and national level, to pursue an austerity program of 
higher taxes and lower government spending.

Politically, the United States had expressed its desire to stay out of European affairs with the Senate's rejection of an American role in the Versailles Treaty and the League of Nations after the War. Economically, U.S. policy sought to restore European stability and international trade. German economic recovery was vital to these aims and to accomplish this, faith in its currency had to be restored. The loan policy had this objective. But as it went along increasingly unsupervised by the American government, it led to spending sprees, especially at the state and municipal level, by German local governments. In a new and fragile democracy they felt this was necessary to survive politically as the economic situation grew worse, but it led to financial instability and increasing political acrimony within Germany, which was racked by political extremism after the war. ${ }^{7}$

The issue of Germany's ability and will to pay was always very close to the heart of the matter. Some economists felt that those responsible for the versailles settlement were ignorant of the most basic facts of trade. 8 He began with the basic economic premise that a nation cannot not sell if it will not buy, that imports pay for exports; sums owed equal sums due. The burden of this postwar readjustment would fall, he felt, on the farmers and other exporters. Mercantilism was dead but nations were 
still trying to practice economic nationalism. He felt that reparations would produce the opposite of what was desired (writing in 1926). In order for Germany to pay, they would have had to export much more than Britain or France. Thus tariffs were a result of looking at national advantage rather than stability for the world economy. He thought that reparations were the greatest obstacle to restoring the markets of Europe, a necessary condition for American

farmers and manufacturers to prosper. He claimed reparations were calculated on Germany's ability to produce rather than its ability to export, especially with regard to the Allied unwillingness to buy.

John Maynard Keynes was another believer in the idea that reparation policy was ill-founded. Writing in the early 1920's, he worked out equations which showed payment would be next to impossible. ${ }^{9}$ He began by citing German losses: colonies, mercantile marine, ten percent of her territory, one-third of its coal producing capacity, threequarters of its iron ore, and two million men. 10

Furthermore, they were suffering currency depreciation and revolution. Even with all this the Allies had to assume that Germany would be able to trade more than it had before the war, because only exports could help them raise the cash or credit they would need to convert payments.

But Germany actually had a negative balance of payments before the War: imports exceeded exports by an average of 74 
million pounds sterling in the five years ending in 1913.11 The total negative balance was not as bad because of interest from foreign securities and profits from shipping, but these would now be eliminated. Among their leading exports were iron, which came largely from now lost territory: machinery, in which increases were possible; coal and coke, of which no increase could be expected; wool, cereal, cotton and leather, from which substantial increases could not be expected. The losses of Alsace-Lorraine and Upper silesia were critical. On top of this, Germany would have to cut imports which would lower the standard of living to an extent that would be politically difficult. Keynes also believed, as economists like Herbert Fraser did, that German ability to pay was calculated on annual surplus productivity rather than surplus of exports. ${ }^{12}$

Keynes wanted to see the Versailles Treaty revised through the League of Nations, specifically under article XIX of the Covenant, which stated: "The Assembly may from time to time advise the reconsideration by Members of the League of treaties which may have become inapplicable and the consideration of international conditions whose continuance might endanger the peace of the world." He realized this was only an advisory capacity and would be difficult to implement, but felt economic changes were necessary for the economic well being of Europe. 13

Keynes proposed a total reparation bill of 2 billion 
pounds sterling, which would include lost property (including ships) and territory, to be paid off over 30 years. ${ }^{14}$ In reality, the Allies ended up demanding over five times that much, 132 billion marks, to be paid off over 60 years. ${ }^{15}$ This total, demanded through the London Ultimatum of May 5, 1921, was eventually accepted by the coalition government headed by Joseph wirth, after the previous government resigned over the crisis. This began the policy of "fulfillment", so distasteful to the Nationalists in Germany, which meant to show through good intentions that the reparations were unreasonable and could never be fully paid. Some felt that Germany launched a successful propaganda campaign against the reparations and that their resistance to paying was more important than the ability to pay, when considering the fact that only about 20 billion gold marks were ever paid. ${ }^{16}$

Keynes also proposed the cancellation of inter-allied debts and sending the reparations to the most damaged countries. The United states was the primary lender, though Brita lent more than it borrowed. Thus the United states would have had to sacrifice the most, having extended credits worth 7.3 billion pounds during the war and another 2.3 billion pounds in the immediate post-war period. 17 Keynes thought the huge, unprecedented amounts caused additional problems because they were inter-governmental and not based on any real property or assets. They were paper 
entanglements that the banks were not used to. He didn't believe that they would be paid for more than a few years. 18 The official American attitude toward reparations was more lenient toward Germany than was that of the allies; they believed capacity to pay should determine the settlement. They also denied the connection with war-debts and resisted Allied proposals for cancellation. Both Wilson and the Republicans who followed him wanted American policy based on the Open Door, a liberal commercial policy of peaceful competition as opposed to the traditional European model of imperialism. At Paris during the peace negotiations, wilson had settled for a somewhat powerless Reparations Commission in the hope that the League would deal with the problem. 19

Secretary of State Hughes continued wilsonian ideals even though he represented the Republicans. His efforts would eventually result in the Dawes Plan. But in March of 1921 a crisis developed between Germany and the Allies over payment of reparations. German Foreign Minister Walter Simons met with British Prime Minister Lloyd George and French Premier Aristide Briand, hoping to convince them to lower the indemnity. If simons could not come up with an acceptable proposal, the Allies would occupy key Rhineland towns and force compliance. On March 21 they did just that and impounded customs receipts to compensate for lack of payment as simon' proposals fell short of approval. ${ }^{20}$ At 
this point, Simons appealed to the American commissioner in Berlin, Ellis L. Dresel. Dresel, in a telegram to Hughes, felt the Germans were more sincere in their efforts to pay a reasonable amount than the Allies gave them credit for. He went on to recognize one of the essential points, "the creation of important sums in foreign exchange is possible for Germany only through a strong increase in its exports." "An enormous increase would be necessary in order to regain great sums and what dangers this would mean for the economic life of other countries." "The financial needs of the Allies can only be taken care of by means of credits. The prerequisite for German credit abroad is Germany's financial responsibility. This, however, is wholly undermined by the Allies themselves who in the Treaty of Versailles have reserved for themselves a first mortgage on the total wealth and all sources of income of the German commonwealth and states." 21 he went on to say that Germany would be willing to take over the Allied debts and would submit to an examination of its ability to pay by a group of unbiased experts. 22

William R. Castle, Jr., the chief of the European Division of the Department of state, warned Hughes to be careful of any mediation role and not give an impression that the united states was mainly interested in building trade, which could cause friction between the United states and the Allies. 23 Hughes then replied to simons that the 
United States still held Germany "responsible for the war and therefore morally bound to make reparation, so far as it be possible." 24

On April 20, Simons asked that president Harding serve as a mediator on the reparations question. He claimed the proposals as they stood would lead to "nothing ahead but political chaos. In his opinion no government could stand which accepted Paris proposals." Simons also maintained that Germany could not allow gold reserves to leave the country because this would decimate the value of the mark. 25 The next day Dresel again communicated to Hughes, relaying German concerns: they wished to know what Germany's annual productive capacity was and how a surplus was to be gained from it and made available. Further, "Germany sincerely trusts that the president of United States will feel he can nominate commission of impartial experts to make investigations and present verdict as to these problems. Germany is willing to agree to such decisions as are based on determinations of the commission." They agreed to make up the difference between "the interest and sinking fund on international loan" with compensation in services and material. They also again expressed a willingness to assume the Allied war-debts. 26 Hughes replied, "This Government could not agree to mediate the question of reparations with a view to acting as umpire in its settlement", but that they "would be willing with concurrence of Allied Governments to 
take part in the negotiations if Germany seeks to resume them on a sound basis." 27

In a conversation with the British and French Ambassadors, Hughes raised the issue of "when the psychological moment had been reached which gave to the Allied Powers the utmost advantage; that it would be a serious thing to press to the point where Germany should succumb to a feeling of pessimism." He maintained that it was a question for economic experts to determine how much Germany should pay, that they should pay to the utmost of their capacity, but that world economic well-being would be served by having Germany a productive power. He also warned of the unforeseen consequences of resorting to occupation as a sanction. 28

On April 28, the Reparations Commission decided unanimously to $\mathrm{fix}$ the reparations at 132 billion gold marks. 29 The United states did not interfere with this decision and the Germans went away disappointed. The Allies threatened occupation of the Ruhr valley, the German government collapsed and the new government pledged to carry out the obligations.

Castle had wanted Hughes to push for American representation on the Reparations Commission, but Hughes was hampered by domestic political objections to such a role. The most ardent anti-internationalists claimed that they would block President Harding's domestic program if Hughes 
carried through and Harding gave in. ${ }^{30}$ senators William Borah and Hiram Johnson fought against involvement in the Versailles Treaty and the political entanglements they were sure would ensue. The Allies did invite the Harding administration to send representatives to participate in various treaty bodies and Hughes did send unofficial observers, such as Roland $W$. Boyden, to sit in on the Reparations Commission, thus skirting around congressional stipulations. ${ }^{31}$ The senators protested but could do nothing. They did, however, make it part of the Treaty of Berlin, the separate peace with Germany, concluded in October, 1921, that the United States repudiated the League of Nations and that the Treaty of Versailles would not be brought up again in the senate for a ratification vote. This search for a way to avoid congressional pressure for non-involvement would help determine Republican foreign policy and led towards the corporatist solution. In this way it was at times more improvisation than design.

Melvyn Leffler believed that the American war debt policy resulted from the "uneasy compromises between hostile branches of government, which themselves were racked by a multitude of conflicting pressures and irreconcilable goals." 32 He analyzed it in the context of the open door thesis, which stated that American foreign policy was guided by domestic pressures to seek foreign markets in order to absorb America's surplus production. He claims historians 
who traditionally called American debt policy short-sighted, provincial, and overly concerned with public opinion, ignored certain groups who recognized the interdependence of the European and American economies. These groups included the Chamber of Commerce of the United States, the National Association of Manufacturers, the National Foreign Trade Council, the American Bankers Association, and the American Farm Bureau; all of whom worried about depreciating foreign currencies and unstable exchange rates. They recognized the link between these problems and the war debt and so they were often the leading proponents of deferred interest payments or the cancellation of part of the debt. In response, they wanted the Allied debtor nations to reduce reparations, balance budgets, stabilize currencies, liberalize trade, and cut armament spending. 33

Leffler claimed that these economic leaders and interest groups did not go for complete cancellation, the logical way to restore European purchasing power and stabilize currencies, because they feared the public reaction and the increase in already heavy domestic taxation that would surely occur. ${ }^{34}$ The burden of paying off the debt would be shifted to the American taxpayer. Instead, they believed they could attack the crux of the problem, the onerous reparations, by contributing to a settlement and then pumping up the European economy with loans. 35 President Harding was aware of this view among the bankers, 
such as Thomas Lamont of J.P. Morgan and Company, and held regular meetings with them. The secretary of the Treasury, Andrew Mellon, asked Congress for exclusive control over these debt questions in June of 1921. Congress refused to go along with this scheme and set up a five man commission, with the secretary as chairman, to deal with the debts. They also set up a payment and interest rate schedule (not less than $4.25 \%$ over a twenty-five year period). 36 congress insisted on its constitutional right to control finances, distrusted the executive branch, and felt exchanging British and French obligations for practically worthless German ones would be foolhardy. 37 They were most interested in avoiding a heavier tax burden on the American people.

Leffler argued that the Harding administration was quite aware of the debt's impact and its link to the reparations problem. In fact they gave serious consideration to the plan of a prominent banker, S.R. Bertron, which advocated Britain cancelling France's debt, France reducing the reparations and gaining the proceeds of a five billion dollar loan to Germany. 38 It was ultimately rejected because they felt congress would fight it to the end and because commerce secretary Hoover thought it would be dangerous for America to become Germany's only creditor. 39

It was because of these pressures that the Republicans sought alternative methods to carry on diplomacy. Initially 
Hughes sought an international committee of businessmen to determine the German capacity to pay. This was unacceptable to the French and British without a reduction in debts. Eventually the administration was able to negotiate a scaling down of the British debt (payment over sixty-two years and interest from 3 to $3.5 \%$ ) which Congress agreed to in light of increasing prosperity after the recession of 1921. The Republicans would get their committee of experts, but this corporatist scheme received its impetus from the conflict between the executive and legislative branch over economic policy in Europe.

The debt cancellation issue was strongest from 1918 to 1923 and probably reached its height in 1920, when a memorandum was signed by forty-four prominent members of banking houses and chambers of commerce which called for debt cancellation consideration. 40 That the debts were eventually scaled down may have been due to a fear that terms that were too strict would result in repudiation, but the Congressional War Debt Commission was never clear on its policy; it was not comprehensive and merely reduced interest (even though the overall effect was to reduce the debt by over 40\%). 41 Both sides, the bankers and congressional leaders tried to use public opinion on their side, but JoanHoff Wilson believed that public opinion was not as big a factor as these leaders thought it was; the war-debt issue was simply not a high priority with the public. ${ }^{42}$ 
Michael Hogan, argued against the old view of history as very short-sighted; he believed there was continuity between the Republicans and wilson and that the United States did react to the reparation-debt problem before the Ruhr crisis. In addition he went beyond the new history to say that cooperation between Great Britain and the United states was greater than any rivalry between the two. 43 In his view the debt restructuring (lowering of the interest rate and lengthening the schedule of payments) with Britain was very significant. It helped to overcome first obstacle to cooperation, especially since Britain passed on some of its savings to other debtors. In addition it began a trend toward finding a model for European stability. 44 He found evidence that the British and American bankers were also in agreement; the Federal Reserve Bank of New York, headed by Benjamin Strong, and the Bank of England, headed by Montagu Norman, both felt that banks should stay above politics. He cited the cooperation on the private level of the reconstruction loan to Austria in 1923, which was requested by the British and for which the House of Morgan helped organize other American banks for participation. 45

Charles S. Maier felt Germany was also moving toward a corporatist scheme because of the failure of German parliamentary politics to achieve consensus. 46 with the weakening of parliamentary influence, interest groups emerged and bargained. Maier identified the most important 
as labor, which was stronger after the war, the cartels, and the ministries of the federal government. The turmoil caused by the acceptance of terms further weakened the government, which, under Chancellor Wirth, sought equilibrium. Conservative elements, such as the banking houses, refused to join in a coalition government with the Social Democrats. Tax questions were central to the whole problem; they had to eliminate the deficit or watch the floating debt rise, which would drive the value of the mark down further, making the transfer problems worse. The conflict between the Social Democrats and the industrialists was at the root of the problem; the government simply did not enjoy enough widespread support to tax as heavily as it needed to, which made the budgetary problems worse and angered the French.

The strength of industry could be seen in its ability to turn back tax proposals, such as the "seizure of real values" (Erfassung der Sachwerte), which meant to take $20 \%$ of all stocks and bonds. The Social Democrats backed down on this as they also had to on a $20 \%$ corporation tax and an ineffectual $4 \%$ property tax. ${ }^{47}$ The Reichsverband der Deutschen Industrie was a strong influence. In July of 1921, Wirth invited fifteen prominent business leaders to help come up with a plan to raise foreign currency. They decided to pledge some assets in order to secure a large foreign loan if the government would drop their socialist 
tax proposals. They also wished to see Gustav streseman's People's Party (DVP) in the government. Many circumstances seemed to conspire against the government in 1921-22: the loss of part of Upper Silesia to Poland, Morgan and the Bank of England turning down the loan proposal, a railroad strike, and emergency legislation which followed the assassination of Matthias Erzberger, who had served as Finance Minister for the Social Democrats. 48 This was followed in June of 1922 by the assassination of Foreign Minister Walter Rathenau, an act which prompted the passage of a law "for the protection of the Republic", as even the political right grew apprehensive at the spread of lawlessness. 49 wirth's government wanted a moratorium on the reparations payments in 1922 as a new crisis brewed. The British and the French were growing further apart in how hard-line they behaved toward Germany. Britain wanted fiscal reform before any loan, France wanted guarantees of payment, such as customs receipts, Germany wanted a guarantee of a loan before any fiscal reform. It seemed that only the United States could break the deadock by some form of debt cancellation, but with the creation of the War Debt Commission under congressional control this seemed impossible. 50 Hoover seemed to go along with Morgan in wanting pledges of fiscal reform before making any loans and American bankers did not wish to go against the British. 51 But neither the British nor the Americans would 
take the initiative while Germany and France were driven further apart by the pressure of the nationalist element in their respective domestic political situations. In America however, sentiment was turning toward some kind of involvement to bring about a solution. The American ambassador to Germany, Alanson Houghton, wrote to Hughes expressing the necessity for action, otherwise, "the Bolshevik tide will sweep restlessly to the Atlantic. This is not mere rhetoric". 52 
1. Beth McKillan, "The Corporatist Model, World War I and the Public Debate over the League of Nations", Diplomatic History, vol. 15, no. 2, Spring 1991, p. 172.

2. Ibid, p. 173 .

3. Ibid, p. 182 .

4. Leffler, "American Policy Toward Western Europe", p. 419 .

5. Ibid., p. 419-420.

6. Selig Adler, The Isolationist Impulse (New York: Free Press, 1957), p. 130 .

7. William C. McNeil, American Money and the Weimar Republic, (New York: Columbia University Press, 1986), this is a general theme of the book.

8. Herbert F. Fraser, Foreign Trade and world Politics (New York: Alfred A. Knopf, 1926), p. 12-20.

9. John M. Keynes, Essays in Persuasion (New York: w.W. Norton \& Co. Inc., 1 $\overline{963),}$ general argument.

10. Ibid., p. 7 .

11. Ibid., p. 9 .

12. Ibid., p. 11 .

13. Ibid., p. 20 .

14. Ibid., p. 22 .

15. Hajo Holborn, History of Modern Germany 1840-1945 (Princeton: Princeton University Press, 1969), p. 601.

16. Sally Marks, "The Myth of Reparations", Central European History, vol. 11, no. 3, 1978, p. 233.

17. Peter Fearon, War, Prosperity and Depression: The U.S. Economy 1917-1945 (Lawrence, University Press of Kansas, 1987), p.11

18. Keynes, Essays in Persuasion, p. 39. 
19. Peter Buckingham, International Normalcy, The Open Door With the Former Central Powers 1921-1929 (Wilmington, Delaware: Scholarly Resources Inc., 1983) p. 107.

20. Ibid., p. 108 .

21. Commissioner at Berlin (Dresel) to secretary of state) Hughes, 23 March 1921, Foreign Relations of the United States, (Washington: United States Government Printing office, 1936) hereafter cited as FRUS, 1921, II:3739 .

22. Ibid., II:37-39.

23. Castle to Hughes, 20 April 1921, FRUS, II:40.

24. Hughes to Dresel, 29 March 1921, FRUS, II:40

25. Dresel to Hughes, 21 April 1921, FRUS, II:42.

26. Dresel to Hughes, 21 April 1921, FRUS, II:43-44.

27. Hughes to Dresel, 21 April 1921, FRUS, II:44-45.

28. Memo by the Under Secretary of State (Fletcher) of a Conversation between the secretary of state and the British and French Ambassadors (Geddes, Jusserand), 25 April 1921, FRUS, II:49.

29. Ambassador in France (Wallace) to secretary of State, 28 April 1921, FRUS, II:54.

30. Buckingham, International Normalcy, p. 110 .

31. Ibid., p. 111 .

32. Melvyn P. Leffler, "The origins of Republican War Debt policy, 1921-1923: a Case study in the Applicability of the Open Door Interpretation", Journal of American History, vol. 59, December 1972, p.585.

33. Ibid., p. 586 .

34. Ibid., p. 588 .

35. Ibid., p. 594 .

36. Ibid., p. 591.

37. Ibid., p. 592-93.

38. Ibid., p. 594 . 
39. Ibid., p. 597.

40. Joan Hoff-Wilson, American Business and Foreign Policy 1920-1933 (Lexington: University of Kentucky Press, 1971), p.122.

41. Ibid., p. 126 .

42. Ibid., p. 131 .

43. Michael J. Hogan, Anglo-American Entente: The Private structure of Cooperation in Anglo-American Economic Diplomacy, (Columbia: University of Missouri Press, 1977), general theme.

44. Ibid., p. 55 .

45. Ibid., p. 63 .

46. Charles S. Maier, Recasting Bourgeois Europe, general theme.

47. Ibid., p. 254-56.

48. Ibid., p. 269-272.

49. Holborn, History of Modern Germany, p. 603.

50. Maier, Recasting Bourgeois Europe, p. 286-87.

51. Ibid., p. 287-88.

52. Ambassador in Germany (Houghton) to Hughes, 23 october 1922, FRUS, 1922, II:171 
CHAPTER III

THE DAWES PLAN AND APOLITICAL DIPLOMACY

The crisis of 1921-1922 turned to disaster in 1923 with the French invasion and occupation of the Ruhr district, Germany's most important industrial region. This action, which began in January, and lasted for about nine months, would stimulate the formation of the experts committee to deal with the reparations problem. The French government of Raymond Poincaré, despite the opposition of Great Britain, took this move in response to the failure of Germany to keep up on its deliveries of coal and telephone poles. Germany was declared in default of its reparations obligations. The French thought this would guarantee payment as well as put them in a dominant position in Europe regarding industrial strength. Previously, they had provided iron ore to Germany, while Germany had provided coal to France. Cooperative cartel arrangements had been discussed by various industrialists, such as Hugo stinnes, but this would now give the French control. ${ }^{1}$ The Germans responded by stopping reparations payments and beginning a strategy of passive resistance, which slowed production to such an extent that it had very serious ramifications not only for the stability of the German mark, but also the French franc, 
which was weakened by enforcement efforts.

The Ruhr occupation not only separated a key part of Germany from the rest of the country, but the government's financial support of the resistance through printing more money was a major factor in the hyper-inflation that destroyed the currency. A coalition government, with Stresemann as Chancellor, finally ended the passive resistance in september. At this point, stresemann allowed the Ruhr industrialists to make their own reparations agreements, evidence of what Maier called the corporatist development in Germany. ${ }^{2}$ stresemann incurred the wrath of the Nationalists, who felt he gave in to the social Democrats. The inflation was also due to a weak government which did not have the power to tax sufficiently, a problem the Nationalists contributed to, though they blamed the Allies for everything. At this point, Maier felt the weimar government was a mere broker for the interests of business, which was trying to arrange for foreign loans, labor, which wanted changes such as protection against excessive hours, and agriculture, which wanted an abolition of the inheritance $\operatorname{tax}^{3}$ Local governments in the Ruhr and Rhineland further compromised the authority in Berlin by carrying on separate negotiations with France. 4

On December 29, 1922, Secretary of State Hughes had suggested, in a speech, that the reparations problem could be addressed by a unbiased committee of experts, with 
American participation. American policy makers, wary of constraints posed by congress as well as skeptical over the possible effects of direct involvement, wanted to direct the course of events through economic intervention. They felt they could do this either through regulating and directing loans or creating favorable debt settlements. 5

Evidence of United states reluctance to get involved and of simultaneous concern over the developments in Europe is clear in the correspondence of secretary Hughes throughout 1923. He expressed concern but was reluctant to commit to involvement. Hughes said that opinion in the United States was divided between sympathy for devastated France and belief that the occupation would prevent Germany from ever being able to pay; not only would their resistance lead to further sanctions, but German credit would suffer and they would never be able to export sufficiently to meet obligations. 6 Hughes also "felt that in all probability there would have to be some preliminary process of investigation in order to determine upon a satisfactory plan." Impartial experts examining the matter would prevent the type of governmental inquiry which through its partiality would be bound to fail. 7 Germany's financial capacity had to be determined and her credit restored. Stabilization of the German currency was essential to any solution, and this would most likely have to involve foreign loans. 
The British pressed the Americans to take some action. The British Chargé Chilton wrote to Hughes, "unity of thought which either renders common action possible or will be successful in finding an early solution appears to be lacking among the European powers. - failing such action, not only Germany but Europe seems to be drifting into economic disaster. In the circumstances, His Majesty's Government have for long entertained the belief that the cooperation of the United States Government is an essential condition of any real advance towards settlement" Furthermore, "the solution of the European problem is of direct and vital concern to her if for no other reason than because the question of inter-allied debt is involved therein." 8 chilton said they would welcome either an official or unofficial delegation.

Hughes expressed the government's desire to take part in such a conference, but under certain conditions: it would have to be advisory; "not for the purpose of binding governments who would naturally be unwilling to pledge their acceptance in advance", the "essential difference" between reparations and Allied war-debts would have to be maintained, and finally, that "the Government of the United states is not in a position to appoint a member of the Reparation Commission inasmuch as such an appointment cannot be made without the consent of the congress. The secretary of State has no doubt, however, that competent American 
citizens would be willing to participate in an economic inquiry". 9 Hughes wanted to involve the United States, but in a way that congress could not hinder the action and in a way that would not commit the United States but would contribute to a solution to the economic problems of Europe which affected the United States to a large extent. He would be conducting diplomacy with private citizens, representatives of the American financial community. The French were also looking for a way to involve the United states as their financial situation had deteriorated under the effects of occupation. But they wanted to "keep within the limits of the Treaty of versailles", which allowed, under paragraph 7, Annex 11, Part VIII, the Reparation Commission "could designate a committee of experts to give their advice and they could ask the cooperation of American experts." 10 They were careful to specify however, that this committee should not be as widely encompassing as the British wanted it to be, nor should it "encroach upon the powers of the Reparation Commission."ll There was also a disagreement as to whether the reparations amount fixed on May 1, 1921 was to stand. Hughes pushed the idea that nothing should be set, that each government should have the right to reject or accept the findings of the committee, but to stipulate conditions beforehand would defeat the purpose. ${ }^{12}$ Hughes was in essence rejecting the French terms. 
The French eventually gave in to the flexibility requested by Hughes. Hughes then put forth the administration's view that they wanted unofficial participation (to avoid the senate's confirmation right under the Treaty of Berlin). He also wanted Charles $G$. Dawes (former supply chief to the American Expeditionary Force and current president of the central Trust company of Illinois) invited to participate as one of the experts.13 The Reparation Commission formally extended an invitation to Dawes and Owen D. Young (chairman of the board of General Electric and the Radio Corporation of America) on December 21, 1923. A statement was released to the press that Dawes and Young "have been invited by the Reparation Commission to sit as members of an expert committee. . as private citizens without instructions and without the obligation of making reports except to Reparation Commission."14 They did not really need instructions from the government however, because they also believed a reparations settlement would help stabilize Germany and help Europe recover, and this would help the United States. ${ }^{5}$ Hughes did meet with Dawes, Young, and Henry M. Robinson (president of the First National Bank of Los Angeles), the third delegate, for two hours before they left for Europe, but they already agreed on their goals. He did provide them with documents and statistics and the services of economic advisor Arthur $N$. Young, who would not sit on any committees. 16 secretary of 
Commerce Hoover provided the delegation with similar assistance. As for the president, he told them, "just remember you are Americans." 17

The main purpose of the conference was to determine Germany's capacity to pay and the experts wanted to remove reparations from politics as much as possible and base them on economic realities, which they hoped would in turn eradicate the instability brought about by the war and its consequences. ${ }^{18}$ To accomplish this, a stable currency and a balanced budget would be necessary in Germany. The critical factor would be the balance of payments; the total amount could not be raised completely from internal sources because transfer problems would occur. This meant they needed to raise funds from exports. But special arrangements had to be made thus a special bank had to be set up in which Germany would deposit funds in a reparation account for allied creditors. They stuck to economic questions and tried to steer away from the occupation question, partly to appease the French and gain their support for the plan. 19 Further stipulations were that the Reichsbank would become independent of the German government, that the total obligation would not be fixed (annual payments would be determined), and that certain industries, including the railroads, would be mortgaged. By February, Dawes could write, "from this time on, I cease to worry", thinking the worst was over. 20 
But finding a compromise amount that satisfied both the French and the Germans proved difficult. Young eventually called on American Ambassador to Germany Alansen Houghton for help and a plan was finally reached in which payments after the first five years would be tied to a prosperity index. A foreign loan of 800 million gold marks to pump up the economy and help restore gold reserves was also a major part of the plan. A Reparations Agent would be in charge of transferring funds, about half of which would come from internal taxation and the rest from the mortgage bonds on German industry. 21 All of this, it was hoped would safeguard stabilization and revive Germany economically. But as Dawes recognized, the plan would not only have to appeal to "the conservative judgement of individuals expected to invest in a preferred loan", the bankers, but also the public and the governments involved, as well as the Reparations Commission. 22 So as much as Hughes and the Republicans wished it could be done, taking the reparations issue out of politics proved impossible.

The ability of the financial experts (the "unofficial diplomats"), especially the bankers, to influence if not make foreign policy was very evident in the proceedings which led to the approval of the Dawes Plan. The whole plan was quite dependent on the loan and future investment in Germany. The bankers were very worried about the impact of the instability in the Ruhr on future lending. Thus J.P. 
Morgan insisted that the Allied governments agree not to intervene in Germany's ability to repay, which was a de facto revision of the Versailles Treaty. ${ }^{23}$ Morgan exerted further leverage over the French by granting them 100 million dollars in credit to prop up the franc as an inducement to agree to the plan. As Houghton explained, "England and America have the franc in their control and can probably do what they want with it." 24 Nationalist opposition to the plan was strong in France, as it was in Germany, for differing reasons, but the more hard-line Poincaré government was voted out and replaced by one led by the leftist Edouard Herriot, who approved the Dawes Plan. 25

A conference was set up in London to put the plan into action. British Prime Minister Ramsey McDonald wanted the United States to send an offical delegation to the conference. Wishing to avoid the appearance of offical participation in European affairs, the administration originally backed off. Soon after, however, President Coolidge announced that the united states would accept the British invitation, "for the purpose of dealing with such matters as affect the interests of the United states and for purposes of information." 26 British bankers, such as Montagu Norman, head of the Bank of England, were also active in both trying to make sure the British got a fair share of German trade and also in trying to influence the choice of the official Reparations Agent. More 
specifically, they wanted the position to go to someone who would represent the interests of the Anglo-American banking community rather than French or American political interests. 27

At the London conference, the Americans were represented by bankers, such as Thomas Lamont and J.P. Morgan, as well as government officials such as Treasury Secretary Mellon, Ambassador Houghton, and Hughes. Hughes was supposedly there unofficially but exerted great pressure on the French to accept the plan or United States economic and diplomatic support could cease. 28 He knew the French were in need of loans for currency stabilization. The whole process was difficult because it involved dealing with Germany as an equal again, something the Allies were still reluctant to do. The governments as well as the financiers had to be satisfied for the whole thing to work. Ambassador to Britain, clark Kellogg, played a key role in getting the French and Germans to agree to a settlement which would free the Ruhr within a year. 29

The issue of who would become the Agent General for Reparations revolved around the political outlook of the choice. "It developed during meeting that there was unanimous desire, with Governments also agreeing, for appointment of an American as Agent General."30 After Young turned the position down and the administration turned down the choice of Norman Davis as too associated with the 
Democratic Party, the former undersecretary in the Treasury Department and liaison between Morgan and the government, $S$. Parker Gilbert, became a candidate agreeable to both the bankers and the administration. The bankers' role at the conference was influential and probably more pro-German than the State Department; "The bankers were fighting the German battles better than they could do it themselves" wrote Kellogg. 31 But this was necessary for the fulfillment of the whole plan as it rested on the 200 million dollar loan that the United States and Allied bankers agreed to make. Another issue that prompted official United States involvement, was the issue of American claims against the former Central Powers and the cost of the American army of occupation. During the negotiations, Hughes had instructed the Ambassador in France to inform Dawes and Young that the United states would disapprove any settlement which did not take into account American claims while providing for the claims of others. ${ }^{32}$ The issue was allowed to sit however, as United States officials decided the time was not right at that point in the negotiations to interject American claims. This was complicated by the fact that American claims would not come under the versailles Treaty as the claims of the Allies would, but under the separate Treaty of Berlin. This meant that they could not have a representative on the Reparations Commission (without the consent of the senate). They were able, however, to secure an American as the 
Reparation Agent General.

In october, the administration decided it was time to press for claims. Hughes told Ambassador Kellogg in London to inform the British that "no facilitation of their proceedings in the future can be expected from the U.S. unless they deal fairly with U.S. claims." 33 British officials did not take this well, believing the American claims settlement with Germany was harder on the Germans than the Allies claim settlement had been, and also because they felt caught between the American demands for debt payments and the French attempts to work themselves out of payments to Britain. ${ }^{34}$ In January 1925, Ambassadors Herrick and Kellogg were eventually able to work out an agreement. 35 The Dawes Plan was a beginning point for the reconstruction of Europe and solid evidence of the collaboration of business and government in attempting to solve what were obviously economic problems and, not so obvious to some, political problems. The state Department might have acknowledged the political nature of the whole process if it were not for the prevailing mood of the country and Congress, both of which were pessimistic about involvement in Europe. So it was that the policy begun by the Dawes Plan drifted away from coordination and toward a loan policy that was increasingly out of control and reckless. 


\section{ENDNOTES FOR CHAPTER III}

1. Holborn, History of Modern Germany, p. 607.

2. Maier, Recasting Bourgeois Europe, p. 356.

3. Ibid., p. 356 .

4. Ibid., p. 369-70.

5. Leffler, "American Policy Toward Western Europe", p. 423 .

6. Hughes to British Ambassador (Geddes), 25 January 1923, FRUS, 1923, II:52-54. I I : 56 .

7. Hughes to Geddes, 23 February 1923, FRUS, 1923,

8. British Charge' (Chilton) to secretary of state, 13 october 1923, FRUS, 1923, I I:68-69.

9. Hughes to Chilton, 15 October 1923, FRUS, 1923, I I $: 71-72$.

10. Conversation of Hughes with French Chargé (Laboulaye), 26 October 1923, FRUS, 1923, II:84.

11. Laboulaye to Hughes, 29 October 1923, FRUS, 1923, I I : 86-87.

12. Memo of Hughes conversation with Laboulaye, 31 October 1923, FRUS, 1923, I I:88-89.

13. Hughes to Ambassador in France (Herrick), 11 December 1923, FRUS, 1923, II:105.

14. Ambassador in France (Herrick) to Hughes, 8 January 1924, FRUS, 1924, 2:109.

15. Costigliola, "Reconstruction of Germany", Business History Review, vol. L, no. 4, winter 1976, p. 495.

16. Buckingham, International Normalcy, p. 134.

17. Ibid., p. 134 .

18. Holborn, History of Modern Germany, p. 618 .

19. Buckingham, International Normalcy, p. 136-37. 
20. Charles G. Dawes, A Journal of Reparations (London: Macmillan and Co., Limited, 1939), p. 135 .

21. Holborn, History of Modern Germany, p. 619.

22. Dawes, A Journal of Reparations, p. 138.

23. Costigliola, "Reconstruction of Germany", p. 491. 24. Ibid., p. 490.

25. Buckingham, International Normalcy, p. 141 .

26. Ibid., p. 142 .

27. Ibid., p. 144 .

28. Ambassador in Paris (Herrick) to Hughes, 2 July 1924, FRUS, 1924, II:136.

29. Buckingham, International Normalcy, p. 145.

30. Hughes to Herrickdor, 23 February 1924, FRUS, 1924, II : 1 .

31. Hughes to Ambassador in Britain (Kellogg), 21 october 1924, FRUS, II: 368 .

32. Buckingham, International Normalcy, p. 147.

33. Herrick to Hughes, 14 January 1925, FRUS, II:143145 . 
THE LOAN POLICY: COORDINATION GONE AWRY

On October 10, 1924, bankers from the United States and the Allied nations arranged a loan of 200 million dollars to Germany to get the German economy going again so that they could make their reparations payments. This was the act that put the Dawes Plan into motion and began what would become a flood of loans to Germany over the next few years. Commerce secretary Herbert Hoover led the way, with the State and Treasury Departments in agreement, in trying to exert pressure on European governments to sign debt agreements and used the threat of an embargo on private loans to get these nations, France, Italy, and Belgium in particular, to reduce military spending and balance their budgets. $^{1}$ At the same time, Benjamin strong, Governor of the Federal Reserve Bank of New York, was using similar pressure to make European governments push inflation down and balance their budgets. He told German leaders that the attitude of American financiers "would be very much governed by the degree to which confidence was felt in political conditions." 2 This had a direct impact on German Foreign Minister Gustav Stresemann's desire to gain a security pact. This realization that security was a prerequisite for 
economic recovery pushed European governments toward the Locarno agreements, which were reached in october 1925 .

The Locarno Treaties established the western boundaries of Germany where they were after versailies and also called for the demilitarization of the Rhineland. Germany would also become a member of the League of Nations, but Stresemann was able to gain the concession that Germany would be freed from having to take part in sanctions that might be imposed under article 16 of the League covenant. This concession meant that the Germans would not have to jeopardize their relationship with Russia by taking part in sanctions that might force them into fighting Russia or into allowing French troops to go through Germany to fight Russia. ${ }^{3}$ British Foreign Minister Austin Chamberlain was concerned about keeping British commitments to a minimum and thus providing a moderating force against French demands. The result was a lack of commitment to guarantees regarding the German borders in the east. The Treaty made the possibility of another Ruhr episode virtually impossible. Troops were evacuated from the Ruhr as well as the right bank of the Rhine in the summer of 1925 and in December Allied troops left the first occupation zone on the left bank. Though all of this failed to satisfy a majority of Germans, it appeared that a political settiement to accompany the Dawes Plan had taker effect.

The impact of American intervention was not lost on 
Stresemann, who commented, "the whole question of the reconstruction of Europe cannot be settled without America", nor British Ambassador to Germany Viscount $D^{\prime}$ Abernon, who said, "In all the more important developments in Germany during post-war years, American influence has been decisive." Without American advice, agreement and approval, "the whole course of policy would be altered." 4 This was strong evidence that America was making a great political impact even though it was refusing to make political commitments. It was the impact of American finance that influenced political decisions.

The American government, especially commerce secretary Hoover, sought to exert some control over these financial influences. Up to this point in history, there was no real precedent in either the United States or in other countries for loan control, though by 1920, voluntary controls over loans to underdeveloped areas, such as Latin America, Russia, and China had been accepted. ${ }^{5}$ But Hoover began to push for systematic control over the foreign loan policy. That they were never able to attain it was one of the most significant facts in the development of modern American economic foreign policy, according to Joan Hoff-Wilson. 6

Hoover met with Harding, Hughes, Mellon, and banking representatives Thomas Lamont and Milton Ailes, and decided that the government should be informed so that "it might express itself regarding the loans." The administration was 
concerned because some loans were starting to be used for military purposes in Europe and the government had no policy to examine or restrict this. Thus Hoover wanted approval powers because first, the banks would go to the government when trouble arose, secondly, the banks should use the information and advice the government could offer, and third, he didn't want loans used for military purposes, for balancing budgets or to bolster inflationary currencies. 7

The bankers, especially Thomas Lamont, representing the House of Morgan, which had provided a large share of the American portion of the Dawes loan, over half of which was American, and Benjamin Strong of the New York Federal Reserve Bank, opposed any federal control. Strong felt control would "influence foreign governments in their domestic policies." He also claimed the government would not know where to draw the line between good loans and bad ones. 8 This may have been true, but uncontrolled loans would have the same effect in the second half of the 1920's. The bankers also would look to the government if things went sour: they wanted protection without control.

After the Dawes Plan, American money began to pour into Germany. American finance had made the commercialization of reparations bonds attractive to foreign investors. The bonds became even more attractive when the Federal Reserve Bank lowered its discount rate from 4.5 to 3 percent. In Germany, the cities, which had become agents for social 
change under the Weimar Republic, became particularly attractive to investors because they became debt free after their original bonds were rendered worthless by the inflation. In addition, under new provisions being worked out, the local governments were not responsible for collecting taxes but were responsible for carrying out welfare programs. ${ }^{9}$ under these conditions, local governments became increasingly willing to spend while they did not have to account for it. There was political pressure to increase social spending during recessionary periods, like the winter of 1925-1926. Resentment by industry because of the amount of loan money the cities were getting caused further political division between the Social Democrats, who headed many local governments, and industry, which aligned itself with the Nationalists. The largest problem was, under the Dawes Plan, governments were supposed to balance their budgets and pursue conservative fiscal policy. This was made very difficult by the recession of 1925 which made governments want to spend to relieve social discontent.

In Germany, the Finance Ministry was conservative, the Economics Ministry was in the middle, and the Labor Ministry was on the left. They all competed in areas which affected foreign policy because the link between domestic policy and reparations policy was based on the supply of foreign capital. 10 The loans allowed freer spending but created danger as well. To help solve this problem, a new 
Reichsbank was created which was more independent of the government and thus hopefully more financially responsible. Hjalmar schacht was appointed head and he pursued a tight money policy. In this way both international and monetary restraints became very influential factors in German foreign policy.

It was easy for Germany to stray from fiscally conservative policy however, because of the volume of loans. Over the next several years, the United States would put up $80 \%$ of the money borrowed by German public credit institutions, $75 \%$ of that borrowed by local governments, and $56 \%$ of that borrowed by German corporations. ${ }^{l}$ Germany was the leading recipient of the 5.1 billion dollars that were lent overseas between 1925 and 1929 and the amount was twice as much as was needed to pay reparations. 12 This flood of loans worried some businessmen and Hoover, but the state and Treasury Departments did not feel the need to get involved. A related problem was arising because the Allies began to expect cash payments, but the reparations balances were not forthcoming and this created fear of a transfer crisis. 13 Another worry was that the German states and cities were pledging assets for these loans that were also pledged to the Allies for reparations. ${ }^{14}$ This bothered the state Department as well as Reichsbank President schacht, who soon had the states and cities getting clearances for loans. The State Department never did demand any proof of these 
clearances from United States banks however. ${ }^{15}$ By 1927 , the State Department was telling the German government to keep strict tabs on these loans but was not checking up on them itself. 15 The problem was definitely coming to the attention of the Reparation Agent, S. Parker Gilbert, however, and he would become the key figure in trying to gain a measure of responsibility over the loan policy, while not officially representing the United states government.

Hoover wanted to coordinate economic and political foreign policy through a policy of loan control, but he was defeated in this by both the bankers and the other forces in the administration and the government. In alliance with the manufacturers, represented by the National Foreign Trade Council, which included such firms as U.S. Steel, standard Oil, Westinghouse, U.S. Rubber, and International Harvester, Hoover's Commerce Department tried to get a condition set on foreign loans which would stipulate that foreigners would have to spend a certain percent of their loans on American goods.l7 Opposition came from Harding, coolidge, the Federal Reserve, Congress, and the Treasury and state Departments. Both Hughes and Frank B. Kellogg, who followed as secretary of state, objected to the infringement on what they considered their prerogative, the making of foreign policy. Hoover, as the driving force behind the corporatist vision with his "associational" views, felt the government could have an informational and organizing role in helping 
industry. 18 The bankers believed however, that industry would benefit from the loans regardless of the type of control Hoover wanted, because it would increase exports. Hoover eventually got his way to a certain extent when the state Department assumed responsibility for controlling foreign loans, but it was a very flimsy control; it never turned down a single loan in the 1920's despite continual warnings from Reparations Agent Gilbert about German fiscal irresponsibility. ${ }^{19}$

Congress also came out against loan control after the Senate Foreign Relations Committee hearings in 1925 and 1927, and increasingly turned the public against it on the grounds that it could end up involving the United states militarily. Ironically, Hoover was against any armed intervention to protect loans, though Hughes and many bankers were for it. In this way, dissension and misunderstanding contributed to the lack of a coordinated policy on loan control. 20 The apparent prosperity of the period from 1925 to 1928, which saw very few defaults, seemed to lull many bankers and the state Department into a false sense of security.

The State Department's attitude on loans was to defer to the the Beratungsstelle, the German federal loan approval board; concerning a loan to the Municipal Gas \& Electric Corporation of Recklinghausen, secretary of State Kellogg mentioned that "the Department would not wish to confront 
that body, before it passes upon particular loans, with a statement thereon of the Department's views." 21 when the German utility wrote to the Department requesting consent, Assistant Secretary Castle reiterated that approval of the Beratungsstelle was not required for corporation loans, and merely warned them: "In view of the large number and amount of offerings of German loans in the American market, the Department believes that American bankers should examine with particular care all German financing that is brought to their attention, with a view to ascertaining whether the loan proceeds are to be used for productive and selfsupporting objects that will improve directly or indirectly, the economic condition of Germany and tend to aid that country in meeting its financial obligations at home and abroad." 22 He went on to mention that the German Federal authorities were against indiscriminate lending when the borrowers are German municipalities with unproductive purposes. He also warned that complications could arise "from possible future action by the Agent General and the Transfer Committee." 23

The attitude toward loans to municipalities did not seem to be much stricter. Concerning a loan of 10 million dollars for the Rhine-Ruhr Water Service Union of Essen, it was admitted that these were "corporate bodies of public character"; as with the Recklinghausen concern, the stock of prospective borrowers was partly owned by the municipality. 
Yet Ambassador Jacob G. Schurman informed Kellogg that the Beratungsstelle did not have jurisdiction over this loan. Further confusion was evident regarding approval of city of Berlin and city of Frankfurt loans which had been approved "in principle" by the Beratungsstelle. 24

Reichsbank President Schacht was very much in favor of loan control, along with Finance Minister Hans Luther. They wanted Germany to direct the loans, not America. Schacht felt only industrial loans would increase the German trade balance, which would stabilize the currency and help balance the budget. He wanted strict control over public loans but the states would not go along with this. Luther then persuaded Reich President Friedrich Ebert to impose emergency powers which would subject all state and city loans to Finance Ministry approval. The Reparations Agent Gilbert agreed with this move completely. 25

Schacht and Luther both saw that tying American money to German prosperity, that is to private industry, would make America much more responsive to German economic welfare and even get them more interested in lowering reparations. If American finance could invest in German local governments, with the guarantee of repayment tied to tax receipts, they would have less incentive to worry about German prosperity. Furthermore, as Luther said, "the foreign lender will not have the same interest in the prosperity of our economy when his capital is insured by 
the public purse and the payments are not exclusively dependent on the prosperity of our economy. . If the guarantee of the public purse were to become a reality, we would soon become absolutely dependent on the foreign capital market." 26

The private loans were often not much more productive, but they were more politically acceptable in the mid-1920's. The conservatives increasingly attacked public spending, but local governments saw it as their only survival. Industry naturally wanted a larger slice of the loan pie and saw that as a way to combat socialism as well. This is what the American policy makers in both government and finance did not realize, that the political struggle within Germany was very much influenced by the direction of their capital. 27 One large effect that the seemingly directionless flow of capital did have was to play havoc with German attempts to impose consistent monetary and fiscal policy. The security of the municipal bonds was so attractive to American investors, that money made it into the cities despite controls. By 1927, what Luther and Schacht had feared was coming true: American bankers were not responding to German economic needs, which at this point was new markets for expansion, but investing in dubious local projects like parks, hotels, and swimming pools. Top international bankers, like Lamont, grew very concerned about the actions of so many less cautious bankers. He 
wrote to Hoover, "the manner in which certain American bankers have been scrambling for all sorts of loans in Europe is little less than scandalous, just because the bond market happens to be so excellent here just now that people can sell almost anything." 28

Still, the line between public and private was often blurred. Investment in the German public sector exceeded that in the private sector from 1924 to 1930, but many of the public investment went toward projects which included gas, electric, and transportation works, all infrastructure projects which benefited industry. 29 Furthermore, private firms competed for public contracts and cities such as Bremen solicited foreign capital which it made available to private industry. Nevertheless, this state "spending", or the socialist tendency that schacht called "Kalte Sozialisierung", became an abstract target for the conservative enemies of the Weimar Republic. 30

Conservative fiscal policy became very difficult to implement during the recession of 1925-26 however, as unemployment rose and conflicts over Germany's ability to pay reparations increased. Revisionist historiography of the last 20 years has generally held that Germany was able to pay reparations, based on its fiscal and monetary policy of 1925 and 1926. But the price they had to pay in domestic turmoil has also become an issue; it is not simply a question of ability to pay. Those who felt Germany was 
not committed to paying reparations claim they didn't continue their policy of high taxation and lowered spending. As William C. McNeil writes, the problem lay in the realities which faced German policy makers and in the transfer difficulty which resulted from Germany's poor trade balance. 31

The balance of trade was a crucial element. Since reparations had to be paid in gold or foreign currency, which could only be earned by a positive trade balance, German ability to export was essential to the working of the whole scheme set up by the Dawes Plan. The trouble was, the Allies didn't want trade deficits. For a while, in 1925 and 1926, depression lowered national income, which reduced ability to import. This worked with a slight deflation to produce a better trade balance. But the unemployment and corresponding increase in social spending undermined this. Raising taxes and balancing the budget would involve heavy social costs.

American tariff policy was harmful to the German trade balance and did not seem to be in concert with efforts made to restore German economic health through the Dawes Plan. The tariff was always a hot domestic political issue and usually a regional concern. The 1922 Fordney-McCumber tariff established a high tariff policy for the 1920's. The most-favored nation status was another aspect of trade policy that made reciprocity a feature of United states 
trade agreements. Wilson and Harding had sought moderate tariffs and the Federal Tariff Commission was granted enlarged powers to deal with the abnormal post-war situation but throughout the decade protectionism won over. Pressure groups which represented specific small and medium size businesses were able to dominate the tariff hearings of the 1920's. As Joan Hoff-Wilson pointed out, the tariff was a stopgap measure, and not a means of coherent policy to deal with the post-war European economic problems. ${ }^{32}$ Though some flexibility was built in by section 315 of the FordneyMcCumber tariff, whereby the president could raise or lower the rate to equalize it according to the domestic cost of production, this was seldom resorted to; only 5 of 38 duty changes under this provision that were approved by Harding and coolidge actually lowered rates in the 1920 's. 33 Hoover, as President, had a nationalistic outlook as well. He appeared to be somewhat inconsistent in defending artifical restraints, high tariffs, while attacking foreign cartels. The state Department also did not discuss tariff duties at international conferences. The tariff issue would slowly build a wedge between big business and the executive and contribute to the breakup of the corporatist structure which had been developing in the 1920's.

In this climate of economic nationalism, it was difficult for the Dawes Plan to be as effective as it might have been. It opened the door for loans which were 
increasingly used to make up for what Germany could not gain through a favorable trade balance. The foreign loans were contributing to budget deficits. In this situation, the Reichsbank was caught in the middle, between the left, which wanted lower rates, and the right, which claimed the high domestic lending rates made Germany dependent on foreign capital. Schacht and Luther continually fought for fiscal responsibility, Luther claiming that "in terms of foreign policy, it is undoubtably impossible to present an unbalanced budget". 34 Reparations Agent Gilbert supported Schacht in his conservative monetary policy, which earned him the wrath of Germans who resented his influence over the economy. In addition, the international bankers favored Schacht's policy. Schacht, in seeking fiscal conservatism, wanted to restrict the flow of foreign capital to Germany, which he believed encouraged fiscal irresponsibility. Gilbert also felt the reckless lending by many American bankers undermined efforts to gain stability and he worked to check this tendency, while at the same time defending the collection of reparations. The efforts of both Gilbert and Schacht seemed to be working as the Beratungsstelle and State Department stepped up their disapproval of excessive public borrowing; the German Advisory Board began effectively restricting loans in late 1927 and the state Department expressed strong objections to a loan of 30 million dollars to the prussian state government to cover 
budget deficits, under strong pressure from Gilbert. They later retreated however, and maintained it was the German Advisory Board's responsibility. This moved the German consul in Washington, otto Kiep, to conclude: "neither in the Cabinet nor in the responsible departments (state Department, Treasury, Department of Commercel led to an authoritative clarification and determination of the fundamentals of loan policy." 35

On october 10,1927 Gilbert created still more resentment among German industry for his interference and uncertainty among American bankers with a highly publicized memo to the Reich Government, which claimed "severe economic reaction and depression if these tendencies are allowed to continue unchecked - . giving the impression that Germany is not acting with due regard to her reparation obligations." 36 Loans did begin to slow down in 1927 and Schacht lowered the Reichsbank's discount rate which encouraged domestic borrowing in Germany. But the transfer problem grew as the loans waned and Gilbert began to realize the transfer protection in the Dawes Plan was a weakness and in need of reform. Sentiment was growing for a new plan for the final settlement of reparations, especially with payment rising to 2.5 billion Reichsmarks in september of 1928 .

William C. McNeil called Gilbert arguably the most influential person in international finance in the last third of the $1920^{\prime} \mathrm{s}^{37}$ Gilbert also operated in complete 
independence from the United states government in carrying out the job of ensuring the flow of reparations payments. His policies had great effect however, on the attitude of the state Department and the bankers towards foreign loans and especially on the German economy. The United States government trusted Gilbert to represent the interests of the United states by representing the interests of American bankers and international finance. Schacht was also a relatively independent operator who influenced the direction of financial conservatism, but for different reasons. Gilbert sought the collection of reparations through fiscal and monetary conservatism, while schacht sought to show that reparations could not be maintained, using the same conservative strategy. However, the lack of an effective loan control mechanism for most of the Dawes Plan period exposed the fragility of the settlement. The loans had created an illusion of prosperity in Germany that was based on extremely shaky ground politically. Division among the political right and left only grew worse, yet American policy makers in the government seemed oblivious to this effect of allowing finance to conduct foreign policy in the absence of a political mandate. Norman Davis called this diplomacy by capitalists "inadequate, undignified and cowardly." 38 But Hughes explained the rationale for this strategy in 1924: "I may give it as my conviction that had we attempted to make America's contribution to the recent 
plan of adjustment a governmental matter, we should have been involved in a hopeless debate, and there would have been no adequate action. We should have been beset with demands, objections, instructions. That is not the way to make an American contribution to economic revival." 39

German hope for a favorable final settlement in 1929 was misplaced because it still depended on a reduction in the Allied war-debts, which the American Congress was still unwilling to go along with. It was not a matter for the bankers to decide and thus the corporatist foreign policy had its limits. Once again it would be a committee of experts that would meet to set up a final settlement and the United States representatives were Owen D. Young, and J. Pierpont Morgan. Once again this was unofficial diplomacy, though Young and Secretary of state Kellogg were in close communication about the proceedings. In fact Kellogg expressed strong opposition to certain elements of the negotiations, especially those that sought to separate reparations payments into two categories and thus tie them to Allied war-debts: "we will be collecting reparations from Germany in satisfaction of the allied debt to us. . the position taken by this government is being most effectively nullified.. The American delegates have failed to maintain the position consistently taken by their government and that their failure to do so may have unfortunate consequences in the future in so far as the protection of 
America's interests are concerned." 40 This statement seems to reveal that the foreign policy collaboration was not in great harmony at this point. The administration in Washington still wanted no recognition of the connection between war-debts and reparations, while the financiers felt it was too obvious to ignore. Though they were not representing the government, Kellogg wanted them to act in the government's interest. The lack of recognition of the connection would be most harmful to Germany.

The Young Plan replaced the Dawes Plan in 1930. It reduced payments from 2.5 billion marks to 1.7 billion annually, and only partially protected transfers. It also brought back limited lending, which had dried up considerably. ${ }^{41}$ That America would not cancel the debt proved to be a major blow to democracy in Germany. The industrialists and conservatives wanted a much better settlement, the Reich government took the blame, and the split between the two would be final. The very next year, 1930, would see huge success by the National Socialists, Hitler's party. As for American policy, they were able to maintain the lack of linkage between war debts and reparations and followed this illusion with a high tariff (Smoot-Hawley) in 1930, which Herbert Feis called the ultimate folly. ${ }^{42}$ This shaky edifice would fall apart under the weight of the Great Depression. 
ENDNOTES FOR CHAPTER IV

p. 425 .

1. Leffler, "American Policy Toward Western Europe",

2. Ibid., p. 426-27.

3. Holborn, History of Germany, p. 625.

4. Leffler, "American Policy Toward Western Europe", p. 427 .

5. Joan Hoff-Wilson, American Business and Foreign Policy 1920-1933, (Lexington: University of Kentucky Press, 1971), P. 104-105.

6. Ibid., p. 106 .

7. Ibid., p. 106-107.

8. William C. McNeil, American Money and the Weimar Republic, (New York: Columbia University Press, 1986), p. 6-8.

9. Ibid., p. 9 .

10. Ibid., p. 10-12.

11. Costigliola, "Reconstruction of Germany", p. 493.

12. Fearon, War, Prosperity and Depression, p. 82.

13. Costigliola, "Reconstruction of Germany", p. 495.

14. Herbert Feis, Diplomacy of the Dollar; First Era, 1919-1932, (Hamden, Conn.: Archon Books, 1965), p. 43.

15. Ibid., p. 44-45.

16. Feis, Diplomacy of the Dollar, p. 46 .

17. Hoff-Wilson, American Business and Foreign Policy, p. 115 .

18. McNeil, American Money and the Weimar Republic, p. 37 .

19. Hoff-Wilson, American Business and Foreign Policy, p.117.

20. Ibid., p. 119-120. 
21. Secretary of state (Kellogg) to Ambassador in Germany (Schurman), 9 January 1928, FRUS, 1928, II:898.

22. Assistant secretary of state (Castle) to Messrs. Hornblower, Miller, and Garrison, 23 January 1928, FRUS, 1928, II : 900 .

23. Ibid., II:901.

24. Schurman to Kellogg, 24 January 1928, FRUS, 1928, I I : 902-903. p. 60 .

25. McNeil, American Money and the Weimar Republic,

26. Ibid., p. 57.

27. Ibid., p. 68 .

28. Buckingham, International Normalcy, p. 150

29. McNeil, American Money and the Weimar Republic, p. 73-81.

30. Ibid., p. 101 .

31. Ibid., p. 111 .

32. Hoff-Wilson, American Business and Foreign Policy, p. 74-80.

33. Ibid., p. 86.

34. McNeil, American Money and the Weimar Republic, p. 115 .

35. Ibid. p. 176-179.

36. Ibid. p. 184 .

37. Ibid. p. 168 .

38. Buckingham, International Normalcy, p. 152.

39. Ibid., p. 151-152.

40. Kellogg to Charge in France (Armour), 8 April 1929, FRUS, 1929, II:1039.

41. Costigliola, "Reconstruction of Germany", p. 492.

42. Feis, Diplomacy of the Dollar, p. 49. 


\section{CHAPTER V}

\section{CORPORATISM UNDER STRESS: THE HOOVER YEARS}

President Hoover presided over American foreign policy during the critical period of the Depression's onset and the last years of the Weimar Republic. He continued the policy of treating economics and politics as two separate fields and this made his Moratorium proposal, his most vital contribution to dealing with the world economic problem, less effective than it could have been. Hoover also continued the policy of using unofficial diplomats, normally represented by the banking community, though their influence waned as the Depression went on. He also, as one of the original proponents, continued the policy of state Department approval of foreign loans. Under Hoover, this approval process seemed to be as shaky and confused as it previously had been.

A loan proposal by the Swedish businessman Ivar Krueger provided a good example of the lack of effective control over loans to Germany. He wanted to loan the German government 125 million dollars in order to gain a monopoly of Germany's match industry in 1929, but he was in no position to loan this much money and so recruited the assistance of the American banking house of Lee, Higgenson 
and Company. ${ }^{1}$

Kreuger also made the loan conditional on the Germans accepting the Young Plan for the revision of reparations, which the state Department was pushing for. ${ }^{2}$ Reparations Agent S. Parker Gilbert voiced objections to not being consulted and he also wanted the state Department involved. He was very disappointed that George Murname, of Lee, Higginson and Company could give no account of how a majority of these credits were to be used. ${ }^{3}$ Gilbert was pessimistic: "there is a real danger that new credits will simply relieve the Government from the pressure that otherwise exists to put its finances in order." Furthermore, he felt the money would result in new expenditures, allow the Germans to postpone reform and thus interfere with the Young Plan and the mobilization of reparations bonds. He was worried about "how far the German Government and other German public authorities are to be allowed to have recourse to the American market for the purpose of financing their budgetary deficits." 4

Undersecretary of State Joseph P. Cotton, acting for Secretary Stimson, was unclear whether the loan was subject to State Department approval. He contacted Lee, Higginson and found that they "have no information to the effect that their agreement is in any way conditioned upon Department's approval", merely that they had discussed it with schacht and the French. Cotton also mentioned in a later telegram 
that presently "we are hardly in a position to close our markets to every request for capital from abroad." 5 Gilbert answered him by pushing him to take a stand and to be aware of the "political risks which necessarily remain until the new plan has gone into full operation." He also reiterated that he was "opposed to the present credit unless it is clearly and definitely understood that the funds are to be applied immediately to the retirement of existing debt." 6 Answering Gilbert, Cotton appeared to want no responsibility for the matter of loan control: "I feel it would be unwise to oppose this loan, first, because it means going in and attempting to control German action to put through the Young Plan, which I deem inadvisable; second, because it is unwise to attempt to control such a foreign loan." He was clearly avoiding the issue of loan control. The loan was soon made. Furthermore, Ambassador Sackett in Berlin "did not want Embassy, if loan failed, suspected of interfering with German Government's financial plans." This perpetuated the situation of official diplomats staying out and allowing the banking representatives to handle diplomacy. 7

The Young Plan loan was carried out in much the same fashion, with the bankers leading the way in establishing a loan of 300 million dollars, two-thirds of which would go to Germany's creditors and one-third of which would help Germany reduce budget deficits. ${ }^{8}$ The reparations were commercialized by selling them as bonds, often in the 
American market. So here the bankers were not only putting the reparations on a commercial basis, but making foreign policy by intervening in German internal affairs (budget deficits). They were also making a de facto connection between war debts and reparations. Thomas Lamont, of the House of Morgan, wanted "the final liquidation of the war so far as the settlement of great economic questions is concerned and obviously it is is greatly to the interest of American trade to have this great Reparations question settled." He also wanted Germany to be "taken effectively out of receivership; that the the heavy mortgage liens upon her railway and industries be abolished, and that she be put upon her honor to carry out her obligations." 9 They were attempting to privatize a political situation, that of Germany's war-caused obligation to the Allies.

Just six months after the Young Plan loan had begun however, Germany wanted further adjustments. Chancellor Heinrich Brüning met with American Ambassador Sackett in Berlin in December of 1930 and suggested a conference in which Hoover and the United States would take the lead. He also wanted an end to the separation of economics and politics: "if this economic conference only dealt with purely economic questions, and was only attended by economic experts, in all probability an unsatisfactory outcome must be expected. The difficulty with all past efforts had been 
that they had regarded the great related questions of disarmament, reparations, debt retirement, and international loan requirements as separate matters, leaving them to specialists. We must get away from this method; above all, for me a complete understanding with France was the truly decisive goal for a pacification of the politics of the whole world", but he feared direct negotiations with France would be hampered by French internal politics. ${ }^{0}$ Ambassador Sackett agreed with Brüning's appraisal and called on Hoover to go along with the conference, but Hoover was not in favor of a conference at this time because of his preoccupation with domestic problems.

At this point, Young advised Hoover that debts and reparations should be reduced by at least twenty percent, which made Lee, Higginson nervous about their possible overextension. ${ }^{1}$ Both Schacht and Luther were, in the spring 1931, calling reparations the cause of the Depression. Brüning was pleading for moderation, but in May the Nazis and the Communists made gains in provincial elections, causing a further polarization of the political situation in Germany.

A serious blow to German hopes for recovery occurred when French pressure prevented a customs union between Austria and Germany. The French applied financial pressure by threatening to withdraw their 200 million dollars in short term securities. German and Austrian attempts to 
borrow elsewhere began a panic which eventually led to the collapse of Austria's largest bank, the Creditanstalt. By June, this had prompted German President Paul von Hindenburg to appeal to Hoover to intervene. ${ }^{12}$ The situation for Hoover was made more serious by the fact that some central and South American countries were also having a hard time meeting their short term loan obligations and a potential total defaut of 4 billion dollars seriously threatened large American banks. 13

Secretary of state stimson was for some form of cancellation of the war debts, while Treasury secretary Mellon came out against such a plan. ${ }^{14}$ Hoover came down in the middle, though he may have tended to favor some cancellation if not for the fact that an election year was approaching. ${ }^{15}$ Ambassador sackett in Berlin convinced him that a financial collapse in Central Europe was imminent and Thomas Lamont suggested that the United States defer on the payment of principle. ${ }^{16}$ Hoover was now seriously considering a moratorium on intergovernmental debts, despite claims by the Treasury Department that he did not have congressional authority for such a move. Between June 9 and June 15, Stimson and Treasury Undersecretary Ogden Mills consulted with several key bankers, including Young, Gilbert, and Federal Reserve Bank of New York Chairman George Harrison, and they all decided that the time was right for a moratorium. 17 Hoover then conferred with key 
members of Congress from both parties and gained enough pledges of support to go ahead with his plans for a moratorium on debt payments.

Though Hoover was still relying to a certain extent on advice from the bankers, they were not as prominent as they had been in actively formulating policy. Certainly the Depression in general was a turning point for corporatist development, but during this particular crisis in the middle of 1931, Hoover increasingly relied on his department heads, especially Stimson, Mellon, and Mills, to formulate policy. Furthermore, a Moratorium on debt payments was also subject to congressional approval, no matter what the bankers advised. In his memoirs, Hoover claimed that he was motivated more over concern for the international economy than concern for the specific interests of New York banks. 18 But these banks did hold over 500 million dollars in short term credits to Germany and a default would have serious consequences. Hoover wanted a psychological boost to result from his Moratorium as well as an easing of the credit situation. Another motivation was to act before Germany did. ${ }^{19}$ As early as March of 1931, Bruning had decided to seek an end to the reparations payments. 20

Stimson was in constant communication with the British, especially Prime Minister MacDonald, Ambassador Ronald Lindsey, and Bank of England chief Montagu Norman. They, along with Ambassador sackett kept him informed that Brüning 
and Foreign Minister Julius Curtius were close to an announcement of a young Plan moratorium of their own. Stimson informed the British of the American plan for a moratorium, which angered Hoover since it had not yet been approved in the United States. ${ }^{21}$ Rather than using the bankers as unofficial diplomats, Hoover was now using the department heads. He sent Treasury secretary Mellon to England to consult with the British about the proposed Moratorium and he decided to go with the Moratorium after receiving Mellon's report. Originally against the plan, Mellon now urged a two year Moratorium, which both stimson and Mills agreed with. Hoover eventually decided on a one year deferment of war debt payments and made his formal announcement on June 20, 1931.

Whether he intended to or not, Hoover had intervened significantly in the political affairs of Europe in general and Germany in particular. Though it may still have been financial diplomacy, a moratorium at this point was critical to Brüning's political survival. Unfortunately for the Americans, a failure to adequately consult the French undermined the effect of the Moratorium.

Stimson called the Moratorium the "boldest and most constructive step taken by the united states in its dealings with Europe since 1918."22 The total indebtedness to the United states had been about 10 billion dollars. This was reduced by about 40 percent in the mid-1920's. By 1931, 
Germany would owe about 400 million on their next payment, about two-thirds of which would go to the united states and most of the rest to France as the other net creditor. Great Britain received about as much in reparations as they had to pay in war debts. 23 so the problem was, as stimson saw it, that success of the plan depended on the French as well; all the debts had to be covered by the Moratorium. Hoover however, was afraid of the diplomatic haggling and publicity that might result, and thereby jeopardize the whole plan. The French were not informed until the day before the announcement. Stimson recorded in his diary the response of French Ambassador Paul Claudel: he said that "it was wonderful, that he had no idea the president would go so far". 24 Nonetheless, the French were not happy about the lack of consultation. MacDonald and stimson felt prior negotiation might have been fatal to the plan and the financial situation because of the reaction to negotiations in both the U.S. Congress and on the part of French extremists on the right. Both at the time and in retrospect, stimson saw the main problem of the day as the lack of flexibility: "Time after time the issues which divided the statesmen of the great powers were those on which they themselves would have been happy to reach agreement - and would have found agreement easy - if they had not feared a hostile verdict from public opinion at home." 25 
The French were upset, not only because of the lack of consultation, but also because they felt the reparations might be officially ended at this point. They saw the main beneficiaries as the American and British banks as well as the German government. This was because the French had already removed much of their credits from Germany after the elections of september 1930, in which the Nazis made their huge breakthrough. The French did realize however, that an American action would be preferable to a German declaration on debts and reparations. Secretary Mellon and Ambassador Walter Edge worked hard to convince the French and were eventually successful. 26

The corporatist model was still operating at this point as private interests were still very powerful in matters of finance and trade. George L. Harrison of the New York Federal Reserve Bank influenced and helped guide stimson in financial matters and the bankers were very instrumental in helping Hoover gain the "standstill" agreements in July of 1931, by which the governments and central banks of the United States, Great Britain, and France agreed to stop liquidating short term German credits. ${ }^{27}$ But the Departments, especially state and Treasury were increasingly responsible for the actual policies and would become more so as the influence of the bankers waned during the deepest part of the Depression in the early 1930's. Another factor that may have been tipping the balance 
away from corporatism, was the recognition that political normalcy was a prerequisite for economic normalcy. At the London Conference in July of 1931, where the details of the Moratorium were hammered out, it was agreed that the Bank for International settlements should form a committee to deal with the German credit problem. The bankers formed the "Basel Committee", but they realized that financial stability and the restoration of German credit would depend on political cooperation, as the Layton-Wiggen Report issued by the Conference emphasized: "Until relations between Germany and other European Powers are firmly established on a basis of sympathetic co-operation and mutual confidence and an important source of internal political difficulty for Germany thereby removed, there can be no assurance of continued and peaceful economic progress." The report went on to state a second problem, "the increase in a snowball fashion" of Germany's foreign debt. They claimed that "action which lies outside our province must first be taken before any long-term German bonds, however well secured, can be sold." 28 The limits of financial diplomacy were becoming very apparent.

Hoover now had to face the question of what should the administration do, regarding Europe, if the financial community would no longer contribute to European stabilization. Hoover asked George Harrison, head of the Federal Reserve Bank of New York, to help convince bankers 
involved with loans to Germany to extend new credits. However, all but one said they would maintain only their existing credits and not grant new ones. Thomas Lamont, for example, said Germany was acting irresponsibly and thus there was no reason for new credits. 29 The bankers would not solve the problem this time; they had gone far enough and could do no more, according to both Lamont and owen young. 30 Corporatism was severely strained in July of 1931. The issue of French security was bound up with the economic problem. France wanted only assurances that the United states would not interfere with any sanctions, but Hoover was still hesitant to make any foreign commitments. It was becoming evident that some new tactics would be needed and Hoover would eventually introduce them with American participation in the disarmament talks and with plans for an economic conference. But, for now, he moved only slowly in this direction.

Historian Edward Bennett concluded that both the failure to consult the French over the Moratorium and the lack of a political settlement were critical factors. ${ }^{31}$ It seems clear from this analysis that it was no longer possible, if it ever was, to influence events in Europe solely through financial mechanisms. Germany needed recognition as an equal among the great European powers and never got it. They never offered a lot in return however, and seemed usually to want to use their relationship with 
the United States to gain credits and reparations revision. France meanwhile, insisted on the Versailles status quo, an artificial superiority. The lack of support from the United States and Britain, evidenced by the Moratorium affair, reinforced this anxiety.

The Moratorium was a bold attempt to deal positively with the financial problems facing Western Europe and the United states but it did not halt the crisis. By 1935, the German default rate on the Young Plan commercialized reparation payments was 99.6 percent. 32 The Bank for International settlement's coordination of monetary policy through the central banks of the leading powers also came too late. The structure based on the private sector was collapsing and the governments could not rescue it at this time. Increasingly, private industry began to strike cartel-like deals to protect themselves, such as the export association formed by General Electric and Westinghouse in 1931 which resulted in a monopoly on electrical parts. 33 Incentives offered by foreign governments also led to investment abroad, especially in Latin America, and also in Germany, where agreements between German and American firms became common.

Business internationalists had enjoyed the "new practical realism" of the unofficial conferences as opposed to the old diplomatic methods of the leading politicians. But this new method didn't take into account the necessary 
political adjustments. Some, like Senator John Roberts and Norman Davis, felt this was an abdication of executive power. 34 Government promoted economic interests abroad but put the economic foreign policy in the hands of private individuals. In December of 1931, Hoover proposed to Congress a temporary readjustment in war debts to countries which needed it. They turned him down and the eventual result was repudiation of payments and a loss to the American taxpayer. Later, when Hoover tried to convince newly elected Franklin D. Roosevelt of the necessity of debt reduction, he was unsuccessful. But America was heavily involved in the affairs of Europe through the corporatist vision of American financial intervention. By the end of summer in 1931, the Journal of the American Bankers Association proclaimed, "the last vestige, the last pretense, of following Washington's advice to avoid European entanglements has been thrown aside.. . Our isolation is at an end". 35 Despite this, the United states government would not completely cancel war debts that would soon go unpaid anyway, nor would they waver from the view that European leaders should solve their own political problems. Two major conferences were in the preparation stages in 1932, in which this American perspective would surface. One was the London Economic Conference, in which F.D.R. would play the key role in the summer of 1933 and the other was the Geneva Disarmament Conference. 
In preparation for the Disarmament Conference, Secretary of state stimson told J. Pierrepont Moffat, the chief of Western European Affairs for the state Department, "the difficulties of the Disarmament Conference are largely a series of bilateral European problems" and "our chief interest, in the preparations for the conference is to help the other nations in making advance preparations for the Conference." 36 This confirmed the view that the U.S. should not take a strong political role in European affairs. The United states army was not substantial enough to be a factor at the conference but "when it came to the navies the guiding principle of our delegation must be that the superiority on the seas of the Anglo-saxon nations must not be imperiled", in order to help preserve peace. ${ }^{37}$ The American delegation was also hampered by Congress, which under the guidance of senator Borah was threatening an end to the appropriation which supported the delegation. 38 Hoover did propose to reduce arms by one-third, but it never happened. "The French are distinctly uneasy, and despite all denials, view the whole proposal as a shrewd move in the chess game of debts and reparations." 39 In the long run, the United States was not interested in proposals that would compromise security. However, the fact that Hoover was involving the U.S. in these two major conferences was an indication that the administration was changing tactics and no longer relying on committees of financial "experts". 
They would now involve high level statesmen and diplomats directly in Europe to work on essentially political problems.

The United States had played a role in disarmament talks in 1922 and 1930 in Washington and London, but had been primarily interested in questions of naval strength. According to Edward Bennett, domestic politics and a naive idealism were always at the forefront of American thinking and this blinded them to the reality of the influence of the balance of power equation that had dominated Europe. 40 Accordingly, they adopted two approaches. The first idea, favored by Norman Davis, the chief delegate to the Geneva Disarmament Conference in 1932, was to make a dramatic proposal, which Hoover did, but which had no chance of acceptance by the French. The second was the decidedly uncorporatist approach of having secretary of state stimson negotiate directly, away from the conference, with the French, British, and German heads of state. 41 He did this but was unable to bring French Premier Andre Tardieu and Chancellor Brüning together. The importance that first Hoover, and later Roosevelt, placed on these disarmament talks meant that they realized a new way had to be found to deal with the problems of Germany and European stability. 


\section{ENDNOTES FOR CHAPTER V}

1. Bernard V. Burke, "American Economic Diplomacy and the Weimar Republic", Mid-America, vol. 54, October 1972, p. 215 .

2. Ibid., p. 216 .

3. Agent General for Reparations (Gilbert) to the Secretary of state (Stimson), 22 March 1930, FRUS, 1930, I I I $: 97$.

4. Ibid., III:97.

5. Acting secretary of state (cotton) to the Ambassador in Germany (Sackett), 24 March 1930, FRUS, 1930, I I I : 98 .

6. Gilbert to Stimson, 25 March 1930, FRUS, 1930, III $: 99$.

7. Burke, "American Economic Diplomacy and the Weimar Republic", p. 223.

8. Ibid., p. 223 .

9. Ibid., p. 223-224.

10. Edward W. Bennett, Germany and the Diplomacy of the Financial Crisis, 1931, (Cambridge: Harvard University Press, 1962), p. 32.

11. Ibid., p. 38 .

12. William Starr Myers, The Foreign Policies of Herbert Hoover 1929-1933, (New York: Charles Scribner and Sons, 1940), p. 174-175.

13. Ibid., p. 180.

14. Hoff-Wilson, American Business and Foreign Policy, p. 138

15. Henry L. Stimson and McGeorge Bundy, On Active Service in Peace and War, (New York: Harper Brothers, 1948), p. 200 . p. 138 .

16. Hoff-Wilson, American Business and Foreign Policy, 
17. Ibid., p. 139-140.

18. Bennett, Germany and the Diplomacy of the Financial Crisis, p. 136-137.

19. Ibid., p. 138-139.

20. Holborn, History of Germany, p. 678 .

21. Bennett, Germany and the Diplomacy of the Financial Crisis, p. 147.

22. Stimson and Bundy, On Active Service, p. 202

23. Ibid., p. 203.

24. Ibid., p. 206.

25. Ibid., p. 207.

26. Bennett, Germany and the Diplomacy of the Financial Crisis, p. 287.

27. Ibid., p. 288 .

28. Ibid., p. 290.

29. Melvyn P. Leffler, The Elusive Quest American's Pursuit of European Stability and French Security, 19191933, (Chapel Hill: University of North Carolina Press, 1979), p. 246-247.

30. Ibid., p. 248.

31. Bennett, Germany and the Diplomacy of the Financial Crisis, p. 307-311.

32. Emily Rosenberg, Spreading the American Dream American Economic and Cultural Expansion, 1890-1945, (New York: Hull and Wang, 1982), p. 161.

33. Ibid., p. 165 .

34. Hoff-Wilson, American Business and Foreign Policy, P. $148-50$.

35. Leffler, "American Foreign Policy Toward Western Europe", p. 431 . 
36. Jay Pierrepont Moffat, ed. Nancy Harvison Hooke, The Moffat Papers, (Cambridge: Harvard University Press, 1956), p. 47 .

37. Ibid., p. 51 .

38. Ibid., p. 67.

39. Ibid., p. 78 .

40. Edward W. Bennett, German Rearmament and the West, 1932-1933, (Princeton: Princeton University Press, 1979), p. 139 .

41. Ibid., p. 143. 
CHAPTER VI

\section{ROOSEVELT AND THE END OF CORPORATISM IN FOREIGN POLICY}

The Disarmament Conference was still in progress and the London Economic Conference was in the planning stages when Franklin D. Roosevelt defeated Herbert Hoover in the election of 1932. Roosevelt had traditionally been an internationalist but the Depression was the main issue in 1932 and getting the country out of its serious economic difficulties was his first priority. He differed from Hoover in that he felt the solution could be found in a strong domestic policy rather than seeking solutions through international mechanisms as Hoover did. This was one difference that would help put an end to corporatism. Another factor was that F.D.R., even though he would eventually agree with the general line of thinking on foreign policy of Hoover's secretary of state, stimson, wished to distance himself from Hoover's recommendations on dealing with the economic problems in Europe. He not only did not want to be associated with Hoover's policies because of the public perception, but also because he did not want to make any firm commitments before he was even in office. The way foreign policy was made changed under the new 
administration, returning to more traditional methods and turning away from the "unofficial diplomats" of the financial intervention days. Roosevelt used men with experience in the executive departments, Congress, and diplomacy, rather than men from the world of finance who did not have offical ties to the U.S. government, to represent the U.S. in European settlements.

Hoover had some firm ideas about war debts, the stabilization of currency and the London Economic Conference which he shared with Roosevelt during several exchanges between the election and F.D.R.'s inauguration. Hoover had already sent stimson to talk to British Prime Minister Ramsey MacDonald in May of 1932 to plan for the conference. This wouldn't be a meeting of "experts" but a meeting which Hoover wanted MacDonald himself to head. The Moratorium would expire in November but the U.S. was still dealing with each country individually on the debt issue. The debtor governments were all requesting extensions and this was the pretense for the meetings between Roosevelt and Hoover. Also present at the first meeting were Ogden Mills, from the Treasury Department, and Professor Raymond Moley, a Roosevelt advisor who concluded, "that the President could scarcely have chosen a field in which there was less probability of sympathetic cooperation between the two administrations." ${ }^{l}$ Hoover wanted to send a delegation to prepare for the conference, an idea which Roosevelt 
rejected, preferring to negotiate through ambassadors and department heads. 2

Roosevelt also made use of secret emissaries, like William Bullitt, who he sent to Europe in December of 1932. Bullitt was a private citizen with a solid grasp of foreign affairs and who also had been part of an American delegation at the versailles conference, during which he went to investigate conditions in Russia. He reported on European attitudes toward the debts: "the outgoing American Administration's policy, if continued by the incoming one, might cause progressive falls of European governments and resulting conditions in some countries bordering on revolution." ${ }^{3}$ Roosevelt also used Thomas Lamont to deal with the French on the debt issue and Norman Davis, who was already serving as a delegate to the Geneva Disarmament Conference and as a member of the planning commission for the economic conference. But F.D.R. was using these people more as gatherers of information rather than makers of policy, as the committees of "experts" had been.

Roosevelt rejected using Hoover's diplomatic machinery of an "interlocking directorate" which would tie together a comprehensive solution at both the London and Geneva talks. 4 Also, Hoover maintained that an "adequate and proper machinery for dealing with the debts then must be created. It is clear ordinary diplomatic agencies and facilities are not suitable for the conduct of negotiations which can best 
be carried on across the table by specially qualified representatives." 5 Roosevelt went along with neither the idea nor the urgency. Not believing in Hoover's theory that foreign problems caused the Depression, he believed that debts, reparations, economic issues (to be dealt with at London), and politics were all separate. He insisted on debt payment as he didn't wish to battle Congress over the issue while pursuing his main goal of independent federal planning at home. He would slowly confirm Hoover's worst fear by becoming an economic nationalist. Historian Joan Hoff-Wilson didn't believe the debt issue was as large in the public mind as policy makers would have it. ${ }^{6}$ she cited the fact that the number of periodical articles on the subject had declined by two-thirds from the high in the mid1920's to 1932. Even the nationalists in Congress had been unable to prevent the debt agreements of the mid and late 1920 's, which had reduced the total debt by forty percent through reduction in interest payments. She felt the leaders didn't attempt to mold public opinion, but merely assumed it had a greater impact on the debt issue than it really did. 7

Stimson, however, felt public opinion was aroused during the Lausanne meetings in June of 1932, when MacDonald, Herriot, and German Chancellor Franz von Papen agreed to reduce reparations by about ninety percent. This still depended on the United states reducing war debts and 
it was the leaks to the press which affected American public opinion and angered Hoover, who told stimson, "in fundamentals, we had no common ground... debts to us could and should be paid; and that the European nations were all in an iniquitous combine against us." 8 stimson had become a "cancellationist", but he was also angered by the British and French attitudes and their effect on American public opinion. He felt that an increase in trade brought about by cancellation would more than compensate for the loss of debt payment. It would also create an atmosphere of political good will. But he had to follow Hoover's orders and could only express his disagreement in his diary, when on November 23, he wrote: "We have to depart from purely legal situation. - there is another side, and we all have to come to it sooner than later. The quicker we get these damn debts out of the way in some settlement the better off we will be." 9 Default began again after the Moratorium in December and became complete a year later in December of 1933, which moved stimson to write that the largest error was to believe "huge interest bearing loans made in emergency conditions for emergency purposes could ever be repaid by one government to another. It simply could not be done, politically. And when to the political differences there was added the peculiar tariff policy of the American nation, the assurance of default became doubly sure." 10 Despite his belief that the debts should be paid, 
Hoover still felt some agreement over the debts had to be reached for the London Economic Conference to work. Hoover believed that failure to reach such an agreement soon would result in general default. ${ }^{1}$ Roosevelt refused to go along with this however. It was not that he was against a settlement, it was just that he did not wish to rush things and make promises before he actually assumed power. In fact, he was willing to waive interest on the British debt and consider all previous interest payments as payment on the principle, with congressional approval. ${ }^{12}$ As with previous administrations, he was often caught between the desire to accommodate the British on one side and the demands of Congress on the other. The Depression had strengthened isolationism in the senate and the "irreconcilables", led by Senator Hiram Johnson, said that Europe had to be rebuilt from within and not with American money. ${ }^{13}$ The British were not interested in this arrangement of cancelling the interest because they wanted a European settlement that also tied the debts to reparations, a connection that Roosevelt, like his predecessors, would not make.

Roosevelt used a strategy of playing one side off against another in setting up his system of advisors and department heads. Historian Arthur Schlesinger, Jr., wrote of him that he divided the powers around him; he "deliberately organized - or disorganized - his system of 
command to insure that important decisions were passed on to the top."14 This was quite evident in the way he built his foreign policy apparatus with two competing and contrary groups. He listened seriously to internationalists like Stimson and Davis, even keeping Stimson's state Department economic advisor, Herbert Feis. His new secretary of state was the internationalist-oriented cordell Hull and Undersecretary was the Wilsonian, William Phillips. In addition, J. Pierrepont Moffat was chief of Western European Affairs and Norman Davis became his ambassador at large. Yet at the same time, he assigned a staunch nationalist, Raymond Moley, to European economic matters as his new assistant secretary of state. It was this rivalry between Moley and Hull which marked the early period of foreign policy. As historian Frank Freidel wrote, "Roosevelt, succeeding a cautious president who had restrained a dynamic secretary of state, instantly reversed the order of things", often keeping both Moley and Hull in the dark as he acted on his own. 15

Roosevelt was against tying the war debts together with other economic issues in a comprehensive settlement. This did not please British Prime Minister MacDonald, who Roosevelt invited to Washington as part of a planning session for the Economic Conference. Roosevelt did not have a specific plan, but wanted an inflationary policy to drive prices up as a means of dealing with the Depression. This 
went against what MacDonald and other European leaders desired, which was currency stability. He was hoping that a nationalistic monetary and economic policy would work fast enough to permit stabilization and tariff agreements at London. MacDonald and former French Prime Minister Herriot had come to Washington hoping for some promises on the debt issue, but were disappointed by Roosevelt's lack of commitment, claiming that he didn't know what congress might allow him to give.

Roosevelt showed a clear departure from the corporatist idea by choosing members of Congress and the state Department as delegates for the London Economic Conference, rather than members of the financial community who did not represent the government. He picked people who spread over a broad spectrum of political viewpoints and also people who had never been to an international conference before. In addition, he clearly had an eye toward appeasing Congress. Along with Cordell Hull, he chose senator Key Pittman of the senate Foreign Relations Committee, former Democratic Party presidential nominee, James Cox, Republican Senator James Couzens, also of the Foreign Relations Committee, Congressman Sam McReynolds, Chairman of the House Foreign Affairs Committee, and Ralph Morrison, a financial backer of the Democratic Party in Texas.

When the Conference opened in June, currency stabilization was a large issue and Roosevelt's 
intransigence on the issue stalled progress. He had taken the United states off the gold standard hoping for a rise in the dollar. Gold countries, such as France, Belgium, Holland and Switzerland, wanted a commitment to stabilization. F.D.R. refused, wishing to keep the United States free to pursue a price raising policy. Throughout the period of the conference, Roosevelt may have delegated duties, but he was making the decisions. He also was not using the bankers, a complete turnaround from the conferences of the corporatist 1920's. He was really finishing off both the corporatist operation and the conference when he delivered his "bombshell" message on July 3 , when he proclaimed, "The sound internal economic system of a nation is a greater factor in its well being than the price of its currency in changing terms of the currencies of other nations. . Old fetishes of so called international bankers are being replaced by efforts to plan national currencies with the objective of giving those currencies a continued purchasing power which does not greatly vary in terms of the commodities and needs of modern civilization." 16 . In publicly rejecting the currency stabilization declaration desired by the western Europeans, he claimed "American investors had trusted the debtor countries as they did their own, and yet they had wound up with worthless or depreciated bonds."17 He also added that the tariff, another issue of the conference, would not be 
lowered to allow dumping. The United states was now turning inward in an economically nationalistic direction. No longer were committees of "experts" seeking international solutions that would benefit the United States; foreign policy was now in the hands of a strong executive.

Roosevelt took a much stronger personal role in the conferences than had earlier presidents in the 1920's. However the approach, while involving members of the government, rather than members of the financial community, seemed to lack the coherence of the corporatist approach. It was true that Roosevelt wanted higher prices while the Europeans wanted stabilization of currency which contributed to a confusion of aims. But as cordell Hull related, the contradictory views characterized the American delegation as well: "Few mistakes can be more unfortunate than for the official head of a delegation to a world conference not to have a chance to consult with the President on the selection of the entire personnel - or at least let the personnel have that distinct impression. Otherwise there is little sense of loyalty or teamwork on the part of some, and open defiance from others." 18 Hull spoke from disappointment at not being able to gain a reduction in trade barriers, his own special desire, which, according to Business week, Roosevelt could have pushed through Congress in April, had he submitted the bill at that time. ${ }^{19}$ But Hull also was frustrated by the attempt of Raymond Moley, the Assistant 
Secretary of state and more of an economic nationalist, to attempt to go over his head and act like the personal emissary of Roosevelt when he wasn't even part of the delegation. Moley was eventually rebuffed, but this added to the confusion and typified Roosevelt's approach of blurring the lines of authority among his underlings to maintain the final decision making capacity. State Department economic advisor Herbert Feis also commented on the preparation for the Economcic Conference in April, that "there could hardly be worse difficulty and confusion than exists." 20 James P. Warburg, who Roosevelt also brought in to work on economic and political relations with Europe, along with Feis and william Bullitt, said of the uncertainty over commercial and economic policy, there are "two warring camps within the administration with no umpire settling the results between them." 21

In the end, Roosevelt was concerned with domestic prices; he wanted them to rise and did not want them set from the outside, and so he rejected the European call for currency stability, dooming the conference. Our aim, he said, was to have "the kind of dollar which a generation hence will have the same purchasing power as the dollar we hope to obtain in the near future." Only "when the world works out concerted policies in the majority of nations to produce balanced budgets and living within their means, then can we properly discuss a better distribution of the world's 
gold and silver supply to act as a reserve base of national currencies." 22 Roosevelt was rejecting a world role. The domestic economy had to be rescued through internal mechanisms, according to Roosevelt, thus pushing aside the Hoover view that the international economic situation was much to blame for America's woes and thus had to be dealt with.

Most of Roosevelt's advisors, including Hull and Moley, were very surprised at the bombshell message of July 3 , that effectively doomed the conference. It showed that the President was acting virtually alone, and and without regard to European interests. Moley related Ramsay MacDonald's reaction: he was "distraught . - The President's action, he bemoaned, had both wrecked the conference and shattered his own personal position." 23

However, F.D.R.'s desires in foreign policy were often kept in check by his realization that domestic policy was his first priority and if he could gain what he wanted in this area, he would need to sacrifice some foreign policy goals. Disarmament was the most important foreign issue for him and his perception of what congress would allow him in this area hampered his ability to make commitments in Europe that might have contributed to some positive results.

The Geneva Disarmament Conference had begun in early 1932. The problem revolved around the German desire for equality, the French desire for security, and the American 
desire for neutrality. As secretary of state under Hoover, stimson believed that Germany had real grievances. He also understood that German foreign policy was a result of the internal strains caused by the existence of a large number of Communists on the left and Nazis on the right. He therefore wanted them to realize that (mutual disarmament) "defenselessness was the best protection in my opinion and would sooner or later force the other countries to reason." 24 It was the French policy which undermined this notion however. Security was all that mattered to them; so much so that Britain felt French preoccupation with security would produce the type of Germany the French most feared. Even Pierre Laval, the French Premier, admitted as much, when he told stimson that the Versailles Treaty's "effect upon Central Europe was an absurdity, but it was a political impossibility to change it." stimson responded by referring to the "oscillation of history back and forth between Germany and France and pointed out the Versailles Treaty froze an extreme oscillation which was unfavorable to Germany at the farthest point of unfavorability - . Any attempt to perpetuate such an oscillation would meet with failure." 25 To this there was no record of Laval's reply, or even if he replied.

Laval wanted a consultative agreement with the U.S. but Hoover had maintained that this was an impossibility. That neither the Americans nor the British would give the French 
any guarantees meant that France had no incentive to disarm. Regarding this situation, stimson told Brüning in April of 1932, that it was like the "unfolding of a Greek tragedy, where we could see the march of events and know what ought to be done, but seemed to be powerless to prevent its marching to its grim conclusion." 26

The two key American delegates to the Conference, Norman Davis and Hugh Gibson, did not report that the French were intransigent however, only that they did not expect any guarantees from the Americans. The French just wanted the United states to "refrain from cutting across the course of action determined on by the League, that would be a maximum which could be hoped for from America."27 It was at this point that Hoover made his proposal for the abolition of most offensive weapons, including tanks, bomber planes, chemical weapons, and large mobile guns, as well as the reduction of land forces by one-third. The French insisted on consultation and the Americans replied that this could not be put in treaty form. 28 The Germans pushed for equality at the conference, which was going nowhere by the time F.D.R. came into office.

The Conference reconvened, after a recess, in February of 1933. By March, serious Nazi terrorism had begun with the Reichstag fire and the ensuing emergency decrees which first outlawed the Communist Party, the alleged perpetrator of the fire, and soon effectively put an end to all civil 
rights in Germany. At Geneva, Ramsay MacDonald claimed, "either Germany is given justice and freedom or Europe will risk destruction." 29 MacDonald put forth a plan that gave both concessions to Germany and reassurance to France. MacDonald also wanted to tie in American involvement with the war debt question, which Roosevelt wouldn't do. 30 MacDonald's plan called for consultation upon the identification of an aggressor, but this would upset the neutrality that congress insisted upon. Still, Roosevelt recognized the German threat: "We regard Germany as the only possible obstacle to a Disarmament Treaty."3l Hull echoed the sentiment after receiving a telegram from Ambassador Hugh Gibson from Geneva. He believed that in the case of a complete breakdown in the Conference, which seemed likely, that Germany would immediately disregard the disarmament clauses of the versailles Treaty and rearm in earnest. 32 In this regard, Gibson reported that the issue was one of relations among the European nations and that American disarmament was no issue at all. What the French were concerned about was the American political position toward Europe. What they wanted to know specifically, was whether, if Germany became an aggressor, the United States would uphold their rights as a neutral and hold to the traditional policy of freedom of the seas, in the case of an application of sanctions against Germany. Gibson favored refraining from any action which would defeat sanctions, in exchange 
for a French guarantee of disarmament. 33

Norman Davis, the chief delegate at the conference for the United States, also recognized both the dangerous consequences of an adjournment and the connection of disarmament to economic questions. Both he and Hull pushed these views on Roosevelt and F.D.R. seemed to take them to heart. It was still Roosevelt's decision however, as he had taken over firm control of the foreign policy process. In May, Roosevelt received Dr. Hjalmar schacht, again the president of the German Reichsbank, who was in Washington to talk about restructuring debts. Roosevelt told Schacht however, that he insisted that Germany remain at current levels in armaments, and that "we would support every possible effort to have the offensive armament of every other nation brought down to the German level." 34 It was at this point that he made his comment about Germany being the main obstacle to disarmament and he wanted schacht to report these views to Hitler as soon as possible. Schacht was more interested in communicating the point that German obligations would no longer be paid in foreign currency, in essence defaulting on securities purchased throughout the 1920 's. Hull reportedly reacted with indignance while Schacht reported that there were no hard feelings. There are differing versions of who got the best of these meetings, the German, or Hull and Roosevelt. 35 Nonetheless, it was indicative of who was now presiding over foreign 
policy, especially issues that dealt with economics. Roosevelt was taking the lead.

The President also asserted himself in a speech on May 16, 1933, which was meant to influence Hitler, who had a speech planned for May 17. He came out strongly for peace, joint security, and the elimination of offensive weapons. Hitler's speech the following day was conciliatory: "Germany is ready immediately to endorse the American President's magnanimous proposal to put up the powerful United states as a guarantor of peace." 36 Along with Davis's speech in Geneva, which called for a United States determination to consult, determine guilt, and take measures to refrain from action which would defeat collective action, the western Europeans were hopeful and F.D.R. himself felt that he had prevented war. But there was too much divergence between Hitler's speech and his actions and Congress gave no endorsement of such a guarantee from the United states The efforts of 1933 were doomed to fail and the United states would turn inward.

Part of the problem was that Roosevelt would not fight the Senate's Johnson Amendment of May 1933, that sought to put a ban on exports in a dispute to all countries involved, taking away presidential discretion. Another was the ignorance of balance of power considerations, as evidenced by Davis' statement for Roosevelt on May 15, 1933: "It does not contribute to peace and stability in Europe to keep the 
largest and most populous of the nations (Germany) in a permanent condition of inequality." 36 German superiority and its desire for further domination of the continent was a major factor in the outbreak of world war I.

Roosevelt had raised the hopes of the western Europeans only leave them disappointed at London and Geneva. Unlike the Republicans who preceded him, he attempted no corporatist way around the impasse, though unlike them, he saw a need for political as well as economic commitments. It was the timing of the political and content of the economic that was disputed. But he had taken the lead, to the point of ignoring the recommendations of his delegation at London, and did nothing to back up Davis' words at Geneva, deferring instead to the Johnson Amendment. The discredited bankers were now on the outside however, as F.D.R. took control of the foreign policy process. He merely chose to sacrifice more control over foreign affairs to gain what he wanted domestically. 


\section{ENDNOTES FOR CHAPTER VI}

p. 210 .

1. Myers, The Foreign Policies of Herbert Hoover,

2. Ibid., p. 211 .

3. Frank Freidel, Franklin D. Roosevelt Launching the New Deal, (Boston: Little, Brown and Company, 1973), p. 107. p. 214

4. Myers, The Foreign Policies of Herbert Hoover,

5. Ibid., p. 215 .

6. Hoff-Wilson, American Business and Foreign Policy, P. 151 .

7. Ibid., p. 154 .

8. Stimson and Bundy, On Active Service, p. 213.

9. Ibid., p. 216 .

10. Ibid., p. 219 .

11. Myers, The Foreign Policies of Herbert Hoover, p. 247 .

12. Freidel, Launching the New Deal, p. 134.

13. Thomas N. Guinsburg, The Pursuit of Isolationism in the United States Senate from Versailles to Pearl Harbor, (New York: Garland publishers, 1982), p. 135.

14. Robert Dallek, Franklin D. Roosevelt and American American Foreign Policy 1932-1945, (New York and London: Oxford University Press, 1979), p. 29 .

15. Freidel, Launching the New Deal, p. 365.

16. Dallek, Franklin D. Roosevelt and American Foreign Policy, p. 38 .

17. Ibid., p. 54 .

18. Cordell Hull, The Memoirs of Cordell Hull, vol. I, (New York: MacMillan and Company, 1948), p. 254.

19. Leffler, The Elusive Quest, p. 350. 
20. Ibid., p. 333.

21. Ibid., p. 343 .

22. Ibid., p. 344

23. Herbert Feis, 1933: Characters in Crisis, (Boston: Little, Brown and Company, 1966), p. 234-236.

24. Stimson and Bundy, On Active Service, p. 271

25. Ibid., 274 .

26. Ibid., p. 277-278.

27. Leffler, "American Policy Toward Western Europe", p. 453 .

28. Ibid., p. 455 .

29. Freidel, Launching the New Deal, p. 374.

30. Ibid., p. 375 .

31. Ibid., p. 397.

32. Hull, Memoirs, I, P. 223.

33. Ibid., p. 224 .

34. Ibid., p. 226.

35. Freidel, Launching the New Deal, p. 398-399.

36. Ibid., p. 403 .

37. Bennett, German Rearmament and the West, p. 509.

38. Ibid., p. 343 
THE UNCERTAINTY OF POLICY APPROACH IN THE MID-1930's

Corporatist historians write about a corporate design or corporate liberalism in the 1930's, but it appears to be confined to domestic politics. Michael Hogan claims to "have tried to show how the Great Depression of the $1930 \mathrm{~s}$ combined with changes in the industrial structure to produce the New Deal coalition", but focuses more on the design of the 1920's and the post-World War II reconstruction of Europe when it comes to foreign policy. ${ }^{l}$ Likewise, Ellis $W$. Hawley writes about the 1930 's "as the efforts of a pluralistic social order with liberal commitments to find private structures and elites capable of correcting perceived ills and malfunctions. . . in which state agencies collaborated with and became attached to private orders." 2 He mentions as examples the Agricultural Adjustment Act, the National Labor Relations Board, and other attempts of state action to produce new private orders. In a related article, Kim McQuaid tells how this corporate liberalism was in recession in the late 1930's because of business disillusionment with the National Recovery Administration. 3

If anything, there was less cooperation and shared 
interests between government and business in the 1930's regarding the international scene. As Emily Rosenberg pointed out, the successful companies had to negotiate their own agreements with foreign governments as business went multinational while governments became nationalistic. 4 She cited the oil companies as a good example. The new administration moved away from liberal internationalism and toward a regulatory system that hopefully would produce new powers for the executive branch.

The Depression had certainly changed the policy of the 1920's. The bankers had lost influence as well as the ability or the desire to loan Germany more money. There was no chance of any continuance of the sort of diplomacy that was characterized by the "committees of experts". Also, the Depression had helped bring Hitler to power in Germany and Nazi aims were very unclear to the United states in 1933, which helped further confuse policy toward Germany.

As early as December of 1931 , a memo prepared in the state Department observed that Hitler's "groups will attain power soon" and that his "program and ideas seem to resemble those of Fascist Italy" especially when it came to the relationship of government and industry. 5 But the early observations on Hitler were also mistaken in one crucial regard; that "Hitlerism is based on the old Hohenzollern and Prussian idea of strong centralization, imperialism and expansion." 6 It is true that Hitler favored these things, 
but it went much deeper than this: as historian Brooks Van Everen pointed out, well into the period when Hitler had already assumed power, American policy makers were still equating Hitler with traditional German conservatism, maintaining that the Nazis relied on the monarchists, the Prussian Junkers, the army officers, and the large industrialists. ${ }^{7}$ As David Schoenbaum pointed out, the Nazi revolution came as much from the lower and middle classes as anywhere, though it didn't come from any one group. 8 Roosevelt and Hull went with the traditional line of thinking in 1933. In his memoirs, foreign policy expert George Kennen was "shocked to realize" that Roosevelt "still pictured Prussian Junkertum as a mainstay of Hitler's power." 9

The administration seemed to be ignoring evidence that the Nazis had widespread support. Ambassador Sackett wrote from Berlin regarding the March 1933 elections that, "Perhaps the most remarkable thing about this election is that an anti-democratic party, with avowed dictatorial aspirations, has managed to obtain power by means of the secret ballot."10 Later, the new Ambassador, William E. Doda, claimed that the revolution would reorganize and restructure society along Nazi lines and George Messersmith, Consul General at the time, wrote that "no government has rested more firmly on the support of a greater proportion of the general population than does the German population of 
today."ll It was the misperceptions in washington of the radical nature of the Nazis that appeared to slow a more dynamic approach to the problem, along with a preoccupation with domestic issues.

The Roosevelt administration in washington was not the only one to be caught by the "Diplomacy of surprise", as Michael I. Handel called it in his book of the same name. He maintained that Hitler went after the diplomatic surprise, or "fait accompli", between 1933 and 1936, by surprising stronger neighbors during a period of rebuilding militarily while trying to avoid retaliation. ${ }^{12}$ After this period, he was able to shift to a strategy of ultimatums, which helped him overcome the Versailles Treaty restrictions and gain what other German leaders had failed to get.

Hitler was not from the old European school of diplomacy, which the other European leaders had hoped and expected he would be, and they recognized this too late. He often used deception, as with the peace speech of May 17, 1933, which was a response to Roosevelt's warning speech of the day before.

Throughout 1933, Germany was looking for a way to gain respectability in the disarmament talks while always looking for a way to make it look like the French would be to blame if the talks failed. They claimed that "At the Disarmament Conference Germany had never demanded more than to be permitted to possess the same means of defense as all other 
States."13 Foreign Minister Neurath wrote "that if a failure of the conference really proves inevitable, the lack of an intention to disarm on the part of France must appear as the cause." 14 when the Germans did pull out of the Conference and the League of Nations in October, the reaction in the United States was against Hitler but more isolationist than ever: Roosevelt and Hull informed Davis in Geneva, that "we are not interested in the political elements or any purely European aspect of the picture". 15 American foreign policy toward Germany was affected by some conflicting reports from Germany. Leon Dominican, the Consul General in Stuttgart, wrote to Hull in April, of the tendency toward the "cynical militarism of their predecessors of pre-Weimar days", perpetuating the idea of a return to conservatism. ${ }^{16}$ The Commercial Attaché in Berlin, Douglas Miller, wrote that the Nazis were "young, ignorant, romantic" misfits, wanting a "return to medieval status where the individual does not have to do his own thinking." 17 He believed that Mein Kampf was propaganda and that the military threat was not great. This was in conflict with some of the other reports and created a certain amount of confusion. Still, Dodd and Messersmith were diplomats that Roosevelt had a lot of faith in, and their reports were consistently pessimistic and full of warning about the situation in Germany.

Besides the conflicting reports, the men most involved 
in the foreign policy process at this time, brought different perceptions and interpretations, and thus different recommendations to the problem of Nazi Germany. Ambassador Dodd, Secretary of state Hull, and the state Department's chief of the Division of Western European Affairs, Jay Pierrepont Moffat, all had an impact on the formulation of policy, yet held divergent views. According to historian Stefan H. Leader, this was important in the early years of the Roosevelt administration, but less so after 1935, when Moffat was transferred and the views of Hull and Dodd became less divergent. 17 Dodd, who wanted cooperation with the European democracies to stop Germany, was an economic determinist, who believed in the value of free trade to avoid conflict, while Moffat was more of an isolationist who also saw a need to protect investments. 18 Hull and Dodd were both influenced by the failure of protectionist policy in the 1920's and early 1930's and its effect on Germany's inability to pay reparations.

Another factor in foreign policy was the attitude of the senate. In early 1934 isolationist sentiment was not at a high point. Roosevelt had relative freedom during this period. He was able to gain the recognition of the soviet Union, in the hope that new markets might be opened. He also worked to keep the Anglo-American-Japanese naval agreements intact at the 5:5:3 ratio, which was eventually rejected by Japan and led to Roosevelt gaining a large 
increase in the naval budget by 1936. The Reciprocal Trade Agreements Act in 1934 led to an increase in trade if not making it freer. By 1935, however, sentiment turned against involvement in European affairs as the threat of war in Europe increased.

Yet in one of the most crucial tests of the administration's ability to influence affairs in Europe, they came up empty. Roosevelt went along with a state Department desire to sponsor a bill that meant the United States would be "willing to consult with other states in case of a threat to the peace, with a view to averting conflict", and would "refrain from any action tending to defeat collective effort" to restore the peace. ${ }^{18}$ Hull called this "a radical change in the traditional attitude of this country toward two old principles -- neutrality and freedom of the seas. It meant that, if other nations instituted sanctions against a nation they deemed an aggressor, we would do nothing to interfere with such sanctions if we determined on our own that the other nations had made the right choice of the aggressor". 19 The senate Foreign Relations Committee moved against it however, and attached amendments that would apply an embargo to both parties in a dispute, taking away the President's discretionary power. Roosevelt did not fight this, despite protest from Hull. This was indicative of what some historians felt was a lack of initiative on Roosevelt's part 
toward foreign policy both at this time and later, especially during the Czech crisis of 1938.21

Aside from the question of what the United States should do about an increasingly threatening Germany, the main issues in American-German relations in the mid-1930's had to do with trade, discrimination against American lenders (especially holders of German bonds), the treatment of Jews, and disarmament (which had to do with the original question). For secretary of state Hull, trade was always a key issue, because of his belief in the contribution of freer trade toward international peace and prosperity. To this extent, Hull didn't like the growing protest against German treatment of Jews because of its possible negative effect on economic relations. Roosevelt told Dodd that the United states could "do nothing" as it was not "not a governmental affair". 22 The state Department economic advisor, Herbert Feis, later summarized the attitude toward tackling the problem of the Nazi treatment of Jews: "that it was inadvisable. . our chances of securing the cooperation of the Nazi regime in international economic and political affairs and in disarmament by interfering to protest the Jewish and other minorities in Germany. Not only inadvisable but probably futile." 23

Of more practical interest to Hull and Roosevelt was the trade issue, because they had more control over it. The trade issue was one which could also put them back into an 
internationalist mode, rather than looking inward. One reason for this was that the first year of the New Deal had not brought quick recovery and some new tactics were in order. The vehicle for this would be the Reciprocal Trade Agreements Act. Lloyd C. Gardner called this act "the basis of New Deal foreign economic policy." 24 In fighting for his trade liberalism, Hull was trying to gain more control over foreign policy for the President and state Department. The key was to gain presidential discretion over the raising and lowering of tariffs and the goal was to restore foreign markets and play a greater role in the world economy. One of President Wilson's special advisors, Edward M. House, had written in Foreign Affairs, that the tariff problem the administration faced was, "how to enable foreigners to earn enough dollars here to pay their debts and to take our exports, without the necessity of foreign loans." 25 Roosevelt received advice from others also, that trade through reciprocal trade agreements could greatly help recovery. The plan would call for an unconditional mostfavored-nation status for those foreign countries which entered into agreements. This meant that a nation would agree to lower tariffs on certain items when the U.S. did likewise, and if third parties received better concessions on the good in question, the U.S. would get the lower rate. Hull received support in his efforts from groups like the American Manufacturers Export Association and the National 
Foreign Trade council. ${ }^{25}$ The Act was eventually passed by Congress in 1934 .

The Trade Agreements Act was also part of Hull's strategy to bring Germany into line through economic measures. Germany was embarking on a program of economic autarky, or self-sufficiency, and in the process, was beginning to take measures to ensure better trade balances. The first act in pursuit of this goal was the announcement on May 8, 1933, that they were suspending interest payments on private debts to American bankers (excluding the Dawes and Young Plan loans and any agreements made after July 15, 1931). 26 The lenders would receive only fifty percent in transferable currency and the rest in scrip, which could be used to purchase German goods or could be redeemed at a Discount Bank for a fifty percent discount. The result was payment on only seventy-five percent of the total, the rest subsidized German exporters. Hull called this one of Germany's "numerous colossal frauds.. This was a wholesale dishonest and fraudulent policy of the German Government to rearm on a gigantic scale by robbing and defrauding all other governments and their citizens of every possible penny - . in order to promote German's scheme of rearmament without precedent in magnitude." 27 Another problem he referred to with these statements was a German law that forbade the removal of profits from Germany of American owned businesses operating there. Furthermore, 
they "invented nearly a score of different reichsmarks with varying exchange rates" and "A nation that made an economic agreement with Germany seldom knew what it was getting in return." 29

The question was, what to do about these things, to give some concessions in the hope it would get better, or to retaliate and risk further damage to the United States' economy. The problem was complicated by the fact that the United states had an enormously favorable trade balance with Germany, unlike most other countries. Britain for example, simply seized the payments for German goods they imported because they did not have a favorable trade balance with Germany. ${ }^{30}$ This strategy worked and Germany stopped discriminating against British lenders. The Germans also chose not to discriminate against Swiss and Dutch bondholders, for example, further angering the Americans and indicating the lack of unified action in European politics which alienated the United states. ${ }^{31}$ The reaction was usually to do nothing but protest.

George Peek, head of the Agricultural Adjustment Administration, fought against Hull's trade policy and wanted to increase trade with Germany at this time, even after Schacht had announced in July of 1934 that Germany would suspend payments on the Dawes and Young loans as well as the others. He tried to influence the President with businessmen and bankers, who "advocated our making an 
arrangement with Germany whereby we would take more of her goods in return for her paying the American holders of the Dawes-Young loans". 32 The state Department set up a committee to deal with this problem. On october 12,1934 , it concluded that no bilateral trade agreement with Germany should be made, because "the whole complexion of affairs may be quite different in a year or two. It is not likely that the current German commercial policy can last for any considerable period of time." ${ }^{33}$ Hull argued further, that any deal with Germany would undermine American efforts at reciprocal trade deals elsewhere and make the United states look hypocritical. Hull won out but not before the Treasury Department had imposed an increased tariff on German goods, a retaliatory measure which prompted Germany to back off in the trade war and debt discrimination. ${ }^{34}$ Nonetheless, German-American relations continued in a negative direction. Despite the souring of official relations, relations between German and American business firms continued to evolve. Many deals went on that contributed to the rearmament of Germany, of which the state Department was either unaware or chose not to interfere. This indicated a lack of coordination between government and business and an undermining of the corporatist scheme. Not only was there a lack of coordination, but a lack of cooperation. Typical of this was the attitude of business during the ItalianEthiopian War, which began in October of 1935: they felt 
they could sell what they wanted, as long as it was legal, and thus proceeded to triple the sale of oil to Italy in less than two months. ${ }^{35}$ This was in complete defiance of Hull's response to the war: "I did not want the aggressor, though forbidden to buy our arms, ammunition, and implements of war, to buy the raw materials out of which he himself could make the sinews of war. Here was the beginning of our moral embargo, so called because it rested on moral rather than on legal foundations." 36

Gabriel Kolko's article, "American Business and Germany, 1930-1941", is full of examples of the trade that went on with Germany which significantly aided German preparedness for war, despite the public stance of American business, which came out against fascism and Nazism. ${ }^{37}$ To begin with, there was the cartel-like collaboration of the German chemical giant, I.G. Farben, which was highly integrated into the government preparation and planning for war, and the American giant, Du Pont. I.G. Farben was involved with exclusive deals with American businesses despite the fact that many American businessmen knew that I.G. Farben was involved in war planning. ${ }^{38}$ standard oil also entered into agreement with I.G. Farben in 1929 for fear of market competition upsetting the world oil price. This agreement actually went uncovered by the United States government until 1941 and greatly contributed to I.G. Farben's rubber development as well as resulting in patents 
for I.G. Farben to develop superior methods for making explosives. Standard Oil fulfilled these patent agreements with I.G. Farben, depriving Britain and France, even after the war began. Furthermore, I.G. Farben received 20 million dollars from the Nazi government, to buy aviation gas from Standard, without the knowledge of the united states government. 39

General Motors was also heavily involved in Germany, producing not just motor cars. Opel, a completely owned subsidiary of G.M., together with Ford, was Germany's largest tank producer by April of 1939, producing over half of Germany's tanks. 40 For the Americans, motivated by a fear of competition, profits were the guiding factor, and if they could not export them, they would reinvest them in Germany. A spokesman for the Dow Chemical Company maintained, "we do not inquire into the uses of the products. We are interested in selling them."4l At the same time, the Germans looked at this business in terms of political goals.

Kolko, a Marxist, concluded that the interest which drove business during this period was class interest; that profits and stability could best be gained by collaboration in the business world in the form of cartels and market agreements. 42 Their actions were not consistent with the interests of the United States government nor with their own publically stated anti-war position. In this way, the 
corporatist model seemed to be turned around, as big business influenced developments in German foreign policy and thus indirectly, united states foreign policy, not only without the consent and approval of the United States government, but often without its knowledge as well.

All of this went against what some of Roosevelt's most valued observers, such as George Messersmith, Consul General in Berlin, advised. He wanted to block trade negotiations and bring on economic instability as a way to bring Hitler down. But even if this didn't work, the United States should not deal with a nation "not willing to protect existing interests, getting ready to repudiate its debts, and asking for new agreements and new credits with which to get raw materials, a good deal of which are destined for rearmament." 43 The Commercial Attaché in Berlin, Douglas Miller, also argued that there was nothing the United states wanted or needed from Germany. Hull, despite his belief in the Reciprocal Trade Agreements Act, did not endorse making such an agreement with Germany, especially after they announced as part of their "new plan", that they would buy only as much from a country as they sold. A treaty was signed, but without the most-favored-nation status. Trade declined to the point where Germany took less than half the amount of imports they had taken from the United states (from 8.4 percent of the United states export total, to 3.7 percent) from 1933 to 1938. Similarly, during the same 
period, the United States share of Germany's total exports declined from 5.4 to 3.3 percent. 44 But most significantly, the export of chemicals, pharmaceuticals, oil, and base metals to Germany increased, including the tripling of petroleum exports from 1934 to 1938. This led Messersmith to comment in 1936, that American firms were "used for the maintenance of German industrial progress and in some important directions for German rearmament, which is obviously not intended for defensive, but aggressive measures." 45 Thus astute observers like Messersmith realized that not only was business not in cooperation with government policy, their actions worked against the state Department goals of disarmament and a reduction in trade with Germany.

1935 and early 1936 proved to be a most critical period for both the deterioration of German-American relations and for Hitler, in his effort to achieve his goals, including the renunciation of the Versailles Treaty. In March of 1935 he began the open repudiation of the Treaty by revealing the existence of a military air force and plans for an army of 550,000 men, which prompted France to double the length of service for its conscripts and Roosevelt to ask for the largest peacetime defense budget in United States history. 46 Even before this, on october I, 1934, Hitler had secretly told Chief of Staff, Ludwig Beck, of his intent to order conscription by April and to keep it secret until then. ${ }^{47}$ 
It was not that Britain and France did not know what was going on. Germany's departure from the League of Nations and the Disarmament Conference had convinced most observers that Hitler would attempt to rearm. By March of 1934, Britain realized that Germany had possibly 350 military aircraft and could produce them at about a rate of 60 per month and that by March of 1935 they could have a fully equipped army of $300,000.48$ at this point, however, their attitude was one of evading the issue because they were still stronger than Germany and that the Treaty could be changed if "negotiated". British Foreign Secretary John Simon wanted permission for Germany to rearm in exchange for a comprehensive European settlement which would revise the Treaty, which France rejected. ${ }^{49}$ Britain and France, along with Italy, condemned the German announcements of March 1935 one month later at the Stresa Conference, the last attempt at coordination against aggression in Europe. But they did nothing and the conference produced nothing of substance. Then in June, without consulting France or Italy, Britain concluded a naval treaty with Germany, which allowed Germany naval expansion to 35 percent of British tonnage and 60 percent of British submarine capability. They were negotiating, bilaterally, an end to the military provisions of the Versailles Treaty.

Hull, Moffat, and Roosevelt all preferred to make no statement and no official announcement was made regarding 
the developments of March. As for the naval agreement between Germany and Britain, the administration even felt it was a step in the right direction. 50 Ambassador Luther was able to report back to Berlin, that though the direction of American policy might be hard to determine for the future, at present the Congress would successfully prevent any intervention in European affairs. "In the final analysis one respects the restoration of German military power as a fact about which other nations can in effect, do nothing." 51 Hitler was beginning to realize that the United states would do nothing and planned accordingly, despite repeated warnings from the key American observers in Germany, Dodd and Messersmith, who agreed that the continued existence of the Nazi regime would give the United states "something to reckon with" and that "innocent isolationism" would bring grief. ${ }^{52}$ Dodd had felt from the beginning that Nazi aggression would probably lead to war without United States intervention. Even when Hitler made a supposedly peaceseeking speech in May of 1935, Dodd saw the smokescreen: "The Hitler speech was designed, very cleverly for him, to divide his opponents and give the necessary time for preparedness - . the solid front of Stresa and Geneva is weakening - . inside Germany arms manufacturers of every possible kind goes on night and day". 53 His assessment was confirmed by the Anglo-German naval agreement.

Other key events and the way they were reacted to, 
showed that the United States was staying out of European affairs, officially, and were to attempt no more of the economic diplomacy of the earlier period. Furthermore, Roosevelt would withdraw from his own efforts to strengthen his ability to influence foreign affairs, by deferring to Congress on key provisions that would have given him more power.

The Italian invasion of Ethiopia was encouraged by the alienation of the allies, especially France and Italy, caused by the Anglo-German naval deal. 54 The United States attempted to stay neutral as the Neutrality Act forbade embargoing only an aggressor, as Hull and Roosevelt had wanted, but applied to all parties at war. American business, despite Hull's "moral" embargo, continued to supply Italy with crucial raw materials. This same "moral" embargo applied to Italy and Germany in their assistance to the fascist cause in the Spanish Civil war. The state Department maintained that they could not put an arms embargo on Germany or Italy because no official state of war existed between them and spain, despite the fact that Germany contributed critical personnel and assistance in the bombing and artillery phases of the war. 55 The embargo on the Republican government in spain helped the fascists win the war.

The final indication that the United States would not intervene in any way, came with the official reaction to 
Hitler's remilitarization of the Rhineland, which effectively ended both the Versailles and Locarno Treaties. Despite the fact that Ambassador Dodd had warned Foreign Minister Neurath of possibly strict economic sanctions, including a cut off in shipments of oil, steel, and cotton, Hitler felt the moment was at hand and that only a French show of military resistance would compel him to halt the reoccupation by German troops of the Rhineland. 56 The American Ambassador in France, Jesse Strauss, asked if Roosevelt or Hull would issue an official protest. Neither did. Roosevelt, just one week before, had extended the Neutrality Act of 1935 for another year, which would keep an arms embargo on all entering a war, preventing support by League members who would fight aggression. On the Rhineland remilitarization, the state Department maintained that the United States had no part in Locarno and that it was not United states business. In his message to strauss, Hull just confirmed that "F.D.R. O.K." in response to this position. 57 Ambassador Luther could write to the Foreign Ministry about the state Department reaction, that "the German step was to have been expected, that it is indeed understandable, since, after all, it is German territory which is involved, and that it promises a pacification of the European atmosphere which would have been unthinkable as long as Germany had not obtained full sovereignty". Also, "In congress circles the reaction, with some exceptions, is 
in general also sympathetic." 58

Roosevelt made one last attempt to deal with Germany when he asked Dodd to notify him if there was an opportunity that he might "personally and secretly" gain a response from Hitler concerning peace and the German foreign policy goals for the next ten years. 59 Dodd talked to schacht, Hans Dieckhoff, who handled American affairs for the Foreign Ministry, and Neurath, all of whom reiterated the German demands for colonies and a condemnation of the Franco-Soviet rapproachment. Roosevelt made no peace initiative and by the end of the year, America regarded Europe's political problems as "hopeless", according to Luther. ${ }^{60}$ Roosevelt did make one other attempt to set up a conference with the British to explore cooperation, but British Prime Minister Chamberlain felt it might be more provocative than preventative, and it never came off.

Chamberlain had told Treasury secretary Morganthau in March, that the "greatest single contribution that the United states could make at the present moment to the preservation of world peace would be the amendment of the existing neutrality legislation".61 But once again, domestic considerations swayed Roosevelt. At this point in 1937 he was in a battle with Congress over the supreme court and gave in on the Neutrality Bill as he had done before, when pushing too hard for presidential discretion on arms embargoes would have, he felt, jeopardized New Deal domestic 
legislation. In October of 1937, Roosevelt gave his "Quarantine" speech, which indicated no change in policy, only warnings about where the world was headed: "a state of international anarchy and instability from which there is no escape through mere isolation or neutrality."62 At this point, German-American relations were almost dead and their would be no more great initiatives to stabilize Europe, economic or otherwise. The corporatist approach had been buried under an onslaught of isolation, economic nationalism, the Depression, and Nazi militarism. 
ENDNOTES FOR CHAPTER VII

1. Hogan, "Corporatism", p. 155.

2. Ellis W. Hawley, "The Discovery and study of Corporate Liberalism", Business History Review, vol. LII, no. 3, Autumn 1978, P. 318-319.

3. Kim McQuaid, "Corporate Liberalism in the American Business Community, 1920-1940", Business History Review, vol. LII, no. 3, Autumn 1978, p. 362-363.

4. Rosenberg, Spreading the American Dream, p. 167.

5. Memo Prepared by the Department of state, 8 December 1931, FRUS, 1932, II:276.

6. Ibid., p. 276.

7. Brooks Van Everen, "Franklin D. Roosevelt and the German Problem", PhD. dissertation, University of Michigan, 1970 , p. 46.

8. David Schoenbaum, Hitler's Social Revolution, (Garden City: Anchon Books, 1967), p. 40 . p. 50 .

9. Van Everen, Roosevelt and the German Problem,

10. Ibid., p. 51 .

11. Ibid., p. 51-53.

12. Michael I. Handel, The Diplomacy of Surprise: Hitler, Nixon, Sadat, (Cambridge: Center for International Affairs, Harvard University, 1971), p. 31-32.

13. Foreign Minister (Neurath) to Reich Chancellor (Hitler), 16 May 1933, Documents on German Foreign Policy (hereafter cited as DGF $), \overline{1933}, C, I$, (Washington: United States Government Printing Office, 1959), p. 447.

14. Neurath to Ambassador in Washington (Nadolny), 15 February 1933, DGFP, 1933, C, I, p. 42. p. 69 .

15. Dallek, Roosevelt and American Foreign Policy,

16. Consul General in stuttgart (Dominican) to stimson, 4 April 1933, FRUS, 1933, II:216. 
37. Gabriel Kolko, "American Business and Germany, 1930-1941", Western Political Quarterly, vol. XV, December 1962, p. 714 . p. 103 .

38. Ibid., p. 715 and offner, American Appeasement,

39. Ibid., p. 719-725, also Offner, American Appeasement, p. 103, Rosenberg, Spreading the American Dream, p. 167-168, and Manfred Jonas, The United States and Germany: A Diplomatic History, (Ithica: Cornell university Press, 1984), p. 222 . p. 103 .

40. Ibid., p. 725, and Offner, American Appeasement,

41. Ibid., p. 726.

42. Ibid., p. 728 .

43. Offner, American Appeasement, p. 95.

44. Ibid., p. 102 .

45. Ibid., p. 103. p. 101 .

46. Dallek, Roosevelt and American Foreign Policy,

47. Handel, Diplomacy of Surprise, p. 39.

48. Ibid., p. 40 .

49. Ibid., p. 41.

50. Jonas, The United States and Germany: A Diplomatic History, p. 219 .

51. Ambassador in Washington (Luther) to Foreign Ministry, 8 April 1935, DGFP, C,4, p. 26.

52. Robert Dallek, Democrat and Diplomat: The Life of William E. Dodd, (New York and London: Oxford University Press, 1968), p. 260 .

53. Ibid., p. 263.

54. Offner, American Appeasement, p. 122.

55. Ibid., p. 160.

56. Ibid., p. 137. 
37. Gabriel Kolko, "American Business and Germany, 1930-1941", Western Political Quarterly, vol. XV, December 1962, p. 714 . p. 103 .

38. Ibid., p. 715 and Offner, American Appeasement,

39. Ibid., p. 719-725, also offner, American Appeasement, p. 103, Rosenberg, Spreading the American Dream, p. 167-168, and Manfred Jonas, The United States and Germany: A Diplomatic History, (Ithica: Cornell University Press, 1984), p. 222 . p. 103.

40. Ibid., p. 725, and Offner, American Appeasement,

41. Ibid., p. 726 .

42. Ibid., p. 728 .

43. Offner, American Appeasement, p. 95.

44. Ibid., p. 102 .

45. Ibid., p. 103 p. 101 .

46. Dallek, Roosevelt and American Foreign Policy,

47. Handel, Diplomacy of Surprise, p. 39.

48. Ibid., p. 40 .

49. Ibid., p. 41 .

50. Jones, The United States and Germany: A Diplomatic History, p. 219 .

51. Ambassador in Washington (Luther) to Foreign Ministry, 8 April 1935, DGFP, C,4, p. 26.

52. Robert Dallek, Democrat and Diplomat: The Life of William E. Dodd, (New York and London: Oxford University Press, 1968), p. 260.

53. Ibid., p. 263 .

54. Offner, American Appeasement, p. 122.

55. Ibid., p. 160 .

56. Ibid., p. 137. 
57. Secretary of State (Hull) to the Ambassador in France (Strauss), 11 March 1936, FRUS, 1936, I:234.

58. Luther to Foreign Ministry, 9 March 1936, DGFP, $\mathrm{C}, \mathrm{V}, \mathrm{p} .67$.

59. Dallek, Roosevelt and American Foreign Policy, p. 124, and offner, American Appeasement, p. 170 .

60. Luther to Foreign Ministry, 24 october 1936, DGFP, C, v, p. 1142 .

61. Dallek, Roosevelt and American Foreign Policy, P. 139 .

62. Jonas, The United States and Germany: A Diplomatic History, p. 226 


\section{CONCLUSION}

It is not the purpose of this paper to explore what happens to corporatism after world war II, though financial intervention does begin to take place in Europe again at that time. The purpose of this thesis was to explore how corporatism lost its way in the $1930^{\prime} \mathrm{s}$ in American foreign policy toward Germany. It was defeated by a number of factors. The old dichotomy of isolationism versus internationalism definitely played a part. The senate established with its rejection of the versailles Treaty that it would not go along with European entanglements and so the Republican administrations of the 1920's sought a way around this obstacle, because they felt intervention would be beneficial to united states interests in the long run; that peace and prosperity could be purchased with American financial intervention to stabilize Europe, which to a great degree, entailed stabilizing Germany.

The corporatist method itself was partly responsible for its own downfall in the $1930^{\prime}$ s. It ignored political realities and connections, especially the effects of massive loans to German governments and the connection between reparations and war debts. Furthermore, it was not always 
clear or certain that the corporatist scheme was a premeditated plan or whether it was merely a reaction to circumstances. The loan control policy was an example of the lack of collaboration and of clear goals. One can not blame just bankers for the Depression, but their overextension to Germany was characteristic of one of the causes of the Depression: speculation and lending without sufficient caution. The experts involved at the highest levels, men like Gilbert, Lamont, and schacht, all worked against this speculative frenzy, but ultimately, without success, indicating further, that the whole scheme was lacking in cooperation. In addition, the use of financial experts who did not represent the government was a reaction to the desire of Congress to keep the United States out of European affairs.

Finally Hoover, and then Roosevelt, as well as the bankers themselves, realized the plan was not working and they had to turn to new tactics. By 1932, Hoover began working for international conferences that would involve statesmen and diplomats. By 1933, Roosevelt was sending senators and department heads to London to iron out the economic difficulties the United states and Europe faced. He was also taking on the policy process himself, both with his influence over the American delegations at the conferences in London and Geneva, and with his speeches that were tailored for Hitler's consumption. 
The United States had put its relations with Germany on an economic basis for much of the inter-war period and realized too late that this influence would have little effect on the Nazi regime. Unfortunately, the corporatist relationship had declined so significantly, that American business was able to contribute to the Nazi build-up, against the best interests of the United States, unlike the 1920 's, when government and the financial sector shared a vision of what was best for the United states. In the 1930's, business defied Hull's "moral" embargo. By the late 1930 's, the government of the U.S. had turned inward to an extent that made initiatives toward Germany and Europe difficult, and they could only wait for war to come and then react to it. Corporatism had not carried united States foreign policy toward Germany through the Depression and was found wanting in dealing with the Nazi government that emerged from the economic catastrophe. 


\section{REFERENCES}

\section{Primary Sources}

Dawes, Charles G., A Journal of Reparations, London, Macmillan and Company, Limited, I939.

Hull, Cordell, The Memoirs of Cordell Hull, vol. I, New York, MacMillan and Company, 1948.

Moffat, Jay Pierrepont, The Moffat Papers 1919-1941, Ed., Nancy Harvison Hooker, Harvard University Press, Cambridge, 1956.

Stimson, Henry L., and Bundy, McGeorge, on Active service in Peace and War, New York, Harper Brothers, 1948 .

United States Department of State, Foreign Relations of the United states, Washington D.C., United states Government Printing office, 1936.

United states Department of state, Documents on German Foreign Policy, Washington D.C., United states Government printing office, 1959.

\section{Secondary sources}

Adler, Selig, The Isolationist Impulse, New York, Free Press, $19 \overline{57}$

Bennett, Edward W., Germany and the Diplomacy of the Financial Crisis, 1931, Cambridge, Harvard University Press, 1962 .

Bennett, Edward W., German Rearmament and the west, 19321933, Princeton, Princeton University Press, 1979.

Buckingham, Peter, International Normalcy, The Open Door with the Former Central Powers 1921-1929, wilmington, Scholarly Resources Inc., 1983.

Burke, Bernard V., "American Economic Diplomacy and the Weimar Republic", Mid-America, vol. 54, no. 4, October 1972 . 
Costigliola, Frank, "The Reconstruction of Germany", Business History Review, vol. L, no. 4, Winter 1976.

Craig, Gordon, and Gilbert, Felix, eds., The Diplomats 19191939, Princeton, Princeton University Press, 1953.

Dallek, Robert, Democrat and Diplomat: The Life of William E. Dodd, New York and London, Oxford University Press, 1968 .

Dallek, Robert, Franklin D. Roosevelt and American Foreign Policy 1932-1945, New York and London, Oxford University Press, 1979.

Feis, Herbert, Diplomacy of the Dollar; First Era, 19191932, Hamden, Connecticut, Archon Books, 1965.

Feis, Herbert, 1933: Characters in Crisis, Boston, Little, Brown and Company, 1966.

Fearon, Peter, War Prosperity and Depression: The U.S. Economy 19 17-1945, Lawrence, University Press of Kansas, 1987 .

Fraser, Herbert F., Foreign Trade and World Politics, New York, AlfredA. Knopf, 1926.

Freidel, Frank, Franklin D. Roosevelt Launching the New Deal, Boston, Little, Brown and Company, 1973.

Gaddis, John Lewis, "The Corporatist Synthesis: A Skeptical View", Diplomatic History, Vol., 10, Fall 1986.

Gardner, Lloyd C., Economic Aspects of New Deal Diplomacy, Boston, Beacon Press, 1964 .

Guinsburg, Thomas N., The Pursuit of Isolationism in the United States Senate from Versailles to Pearl Harbor, New York, Garland Publishers, 1982 .

Handel, Michael I., The Diplomacy of Surprise: Hitler, Nixon, Sadat, Cambridge, Center for International Affairs, Harvard University, 1971.

Hawley, Ellis W., "The Discovery and Study of Corporate Liberalism", Business History Review, vol. LII, no. 3, Autumn 1978.

Hearden, Peter, Roosevelt Confronts Hitler, Dekalb, Northern Illinois University Press, 1987. 
Hoff-Wilson, Joan, American Business and Foreign Policy 1920-1933, Lexington, University of Kentucky Press, 1971 .

Hogan, Michael J., Anglo-American Entente: The Private Structure of Cooperation in Anglo-American Economic Diplomacy, Columbia, University of Missouri Press, 1977.

Hogan, Michael J., "Corporatism", Journal of American History, Vol. 77, June 1990.

Hogan, Michael J., and Patterson, Thomas, eds.,

"Introduction", Explaining the History of American Foreign Relations, New York, Cambridge University Press, 1991.

Holborn, Hajo, History of Modern Germany 1840-1945, Princeton, Princeton University Press, 1969.

Jonas, Manfred, The United States and Germany: A Diplomatic History, Ithica, Cornell University Press, 1984 .

Keynes, John M., Essays in Persuasion, New York, W.W. Norton and Company, Inc., 1963.

Kolko, Gabriel, "American Business and Germany, 1930-1941", Western Political Quarterly, vol. XV, December 1962.

Leffler, Melvyn, "The Origins of Republican War Debt Policy, 1921-1923: A Case Study in the Applicability of the Open Door Interpretation", Journal of American History, vol. 59, 1972 .

Leffler, Melvyn, The Elusive Quest America's Pursuit of European Stability and French Security, 1919-1933, Chapel Hill, University of North Carolina Press, 1979.

Leffler, Melvyn, "Political Isolationism, Economic Expansionism, or Diplomatic Realism: American Foreign Policy Toward Western Europe 1921-1933", in Perspectives in American History, Cambridge, Cambridge University Press, 1984 .

Leader, Stefan H., Intellectual Processes in Foreign Policy Decision Making: The Case of German-American Relations, 1933-1941, Buffalo, State University of New York Press, 1971 .

Mckillan, Beth, "The Corporatist Model, World War I and the Public Debate over the League of Nations", Diplomatic History, vol. 15, no. 2, spring 1991. 
McNeil, William C., American Money and the Weimar Republic, New York, Columbia University Press, 1986.

McQuaid, Kim, "Corporate Liberalism in the American Business Community, 1920-1940", Business History Review, vol. LII, no. 3, Autumn 1978 .

Maier, Charles S., Recasting Bourgeois Europe, Princeton, Princeton University Press, 1974.

Maier, Charles S., "Marking Time: The Historiography of International Relations", in The Past Before Us, Contemporary Historical Writing in the United States, Michael Kammen, ed., Ithica, Cornell University Press, 1980 .

Marks, Sally, "The Myth of Reparations", Central European History, vol. 11 , no. 3, 1978 .

Myers, William Starr, The Foreign Policies of Herbert Hoover 1929-1933, New York, Charles Scribner and Sons, 1940 .

Paterson, Thomas G., "Defining and Doing: a Primer", Explaining the History of American Foreign Relations, New York, Cambridge University Press, 1991.

Rosenberg, Emily, Spreading the American Dream American Economic and Cultural Expansion, 1890-1945, New York, Hull and Wang, 1982 .

Schoenbaum, David, Hitler's Social Revolution, Garden City, Anchon Books, 1967 .

Stromberg, Roland, "American Business and the Approach of War, 1935-1941", Journal of Economic History,

vol. XIII, winter 1953.

Van Everen, "Franklin D. Roosevelt and the German Problem", PhD. dissertation, University of Michigan, 1970.

Weinberg, Gerhard L., The Foreign Policy of Hitler's Germany, Chicago, University of Chicago Press, 1970. 